\title{
Efficient construction of novel carbocyclic frameworks via intramolecular aromatic addition of diazoketones followed by Diels- Alder cycloaddition
}

\author{
Patrick O’Leary ${ }^{a, b^{*}}$ and Anita R. Maguire ${ }^{a^{*}}$ \\ ${ }^{a}$ Department of Chemistry, Analytical and Biological Chemistry Research Facility, University \\ College Cork, Cork, Ireland \\ ${ }^{b}$ Current adress: School of Chemistry, NUI-Galway, Galway, Ireland. SMACंT (Synthetic \\ Methods: Asymmetric Catalytic Transformations) \\ Email:patrick.oleary@nuigalway.ie;
}

\begin{abstract}
Rhodium catalysed intramolecular aromatic additions of diazoketones followed by Diels-Alder cycloadditions with carbon-based dienophiles leads in a highly stereoselective manner to polycyclic frameworks containing eight stereogenic centres completely controlled by the single stereocentre present in the diazoketone precursor. These cycloadditions provide interesting mechanistic insight into a dynamic equilibrium in methoxy-substituted azulenones.
\end{abstract}

Keywords: Rhodium, catalysis, diazoketone, Diels-Alder, stereoselective, azulenone

\section{Introduction}

Rhodium catalysed reactions of diazocarbonyl compounds are synthetically versatile providing a range of reaction pathways depending on the nature of the substrate and the reaction conditions. ${ }^{1}$ Furthermore, the mild reaction conditions associated with these catalysed processes renders them ideal for adaptation to tandem or at least sequential one-pot processes thereby increasing molecular complexity enormously in a single pot. Padwa has very elegantly demonstrated the strength of combining carbenoid cyclization followed by Diels-Alder cycloaddition in building up complex carbocycles (Scheme 1). ${ }^{2 a-c}$ Other groups have used a similar process to synthesise highly oxygenated epoxy-bridged tetrahydropyranone frameworks. ${ }^{2 \mathrm{~d}}$ 
<smiles>COC(=O)C#CCOC(=O)C(=N)C(=O)OC</smiles>

\section{Scheme 1}

Our group has previously demonstrated efficient, stereoselective construction of polycyclic systems via an intramolecular aromatic addition reaction of suitably substituted $\alpha$-diazoketones followed by PTAD cycloaddition as summarized in Scheme 2. ${ }^{3}$ This paper develops this concept through the synthesis of a series of novel carbocyclic frameworks with complete diastereocontrol. Evidently the synthetic utility of carbocyclic frameworks is significantly greater than the earlier PTAD adducts.

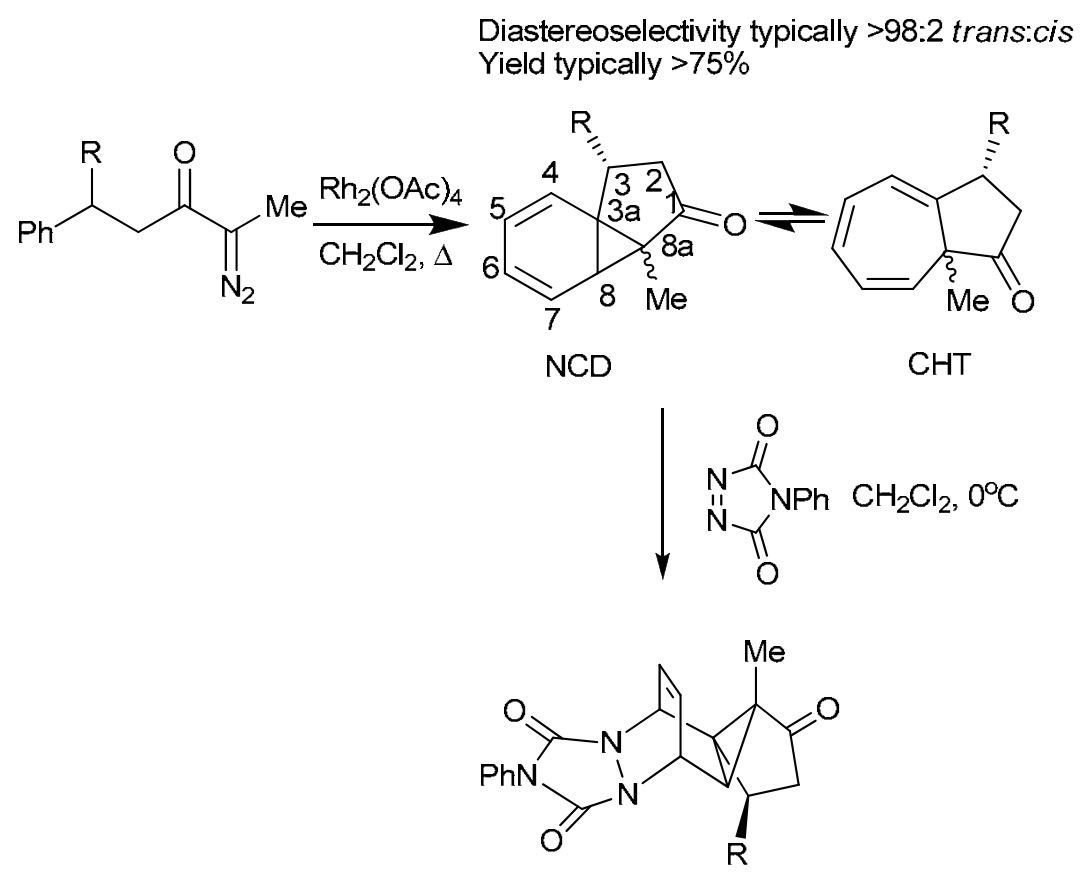

\section{Scheme 2}

The intramolecular Buchner or aromatic addition reaction has been a very active area of research in our laboratory over the past number of years with excellent diastereocontrol achieved in the cyclisation process resulting predominantly in the trans substituted product with the stereochemistry of the new quaternary bridgehead centre essentially completely controlled by the existing stereogenic centre at C-5, $\beta$. to the carbonyl group. ${ }^{3,4}$ The azulenones exists as two rapidly equilibrating tautomers: the norcaradiene (NCD) and cycloheptatriene (CHT) forms. Both the position of this tautomeric equilibrium and the azulenone stability are very sensitive to 
the steric and electronic effects of substituents on the bicyclic skeleton. Our group has been actively investigating the factors which influence the efficiency of and stereocontrol in this transformation including catalyst and substituent effects. ${ }^{3}$ The diastereomeric azulenones are distinguished via the relative orientation of the substituents at the 3 and 8a positions. Trapping the NCD tautomer of the azulenones with the very reactive dienophile 4-phenyl-1,2,4-triazoline3,5-dione (PTAD) proceeded very efficiently to produce a series of crystalline adducts (Scheme 2), the X-ray crystal structure of one of which confirmed the relative stereochemistry in the azulenones. The azulenone reacted exclusively through the NCD tautomer in a [4+2] cycloaddition. This Diels-Alder cycloaddition could be conducted on purified azulenone or indeed in a one-pot process from the diazoketone with no apparent decrease in efficiency.

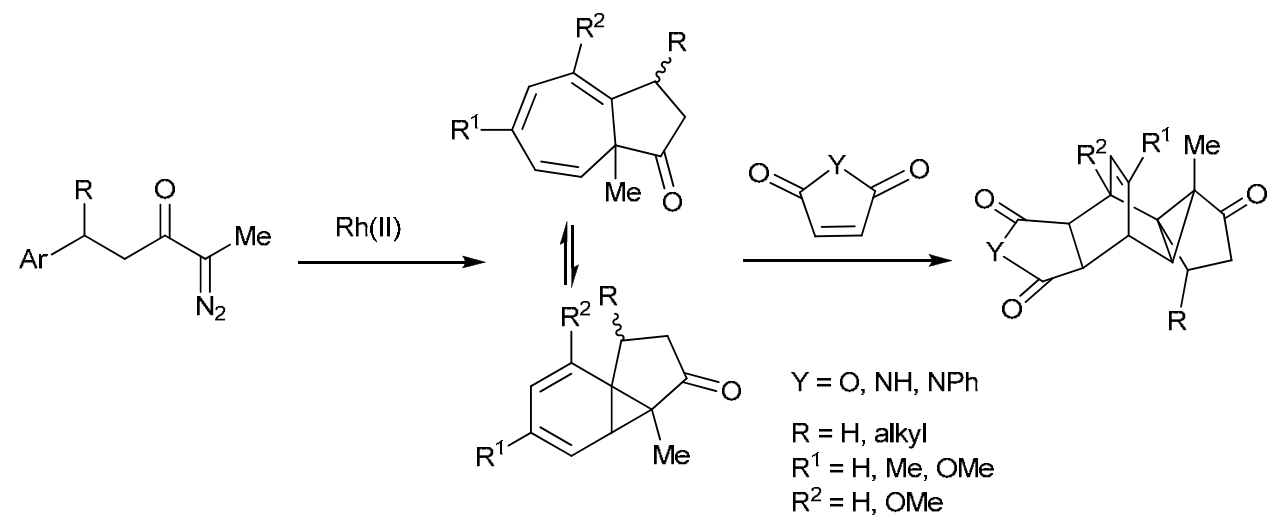

\section{Scheme 3}

While the PTAD cycloaddition proceeded efficiently and with excellent stereoselectivity, it was envisaged that Diels-Alder cycloaddition with carbon-based dienophiles would produce the analogous carbocyclic frameworks and would be of greater synthetic utility (Scheme 3) with complete diastereocontrol expected in the formation of the seven new stereogenic centers in the adducts based on the single pre-existing centre.

In this work the development of the cycloaddition reaction with carbon-based dienophiles is discussed. Notably PTAD is a very reactive dienophile ${ }^{5}$ - with each of azulenones studied, cycloaddition was complete within minutes; only in the case of azulenones with a 3-tert-butyl substituent was a slight decrease in reaction rate observed with cycloaddition requiring up to 30 minutes to reach completion. ${ }^{3}$ However, reaction with the less reactive carbon based dienophiles was expected to be slower, and thereby provide greater insight into the relative reactivity of the azulenones as dienes. 


\section{Results and Discussion}

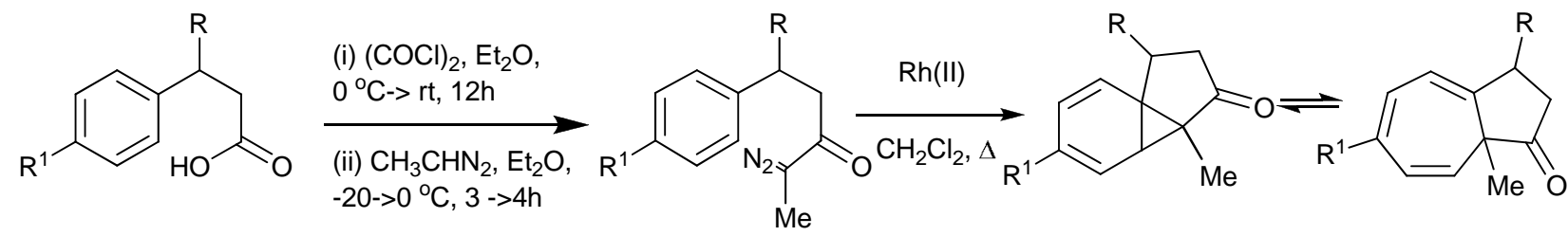

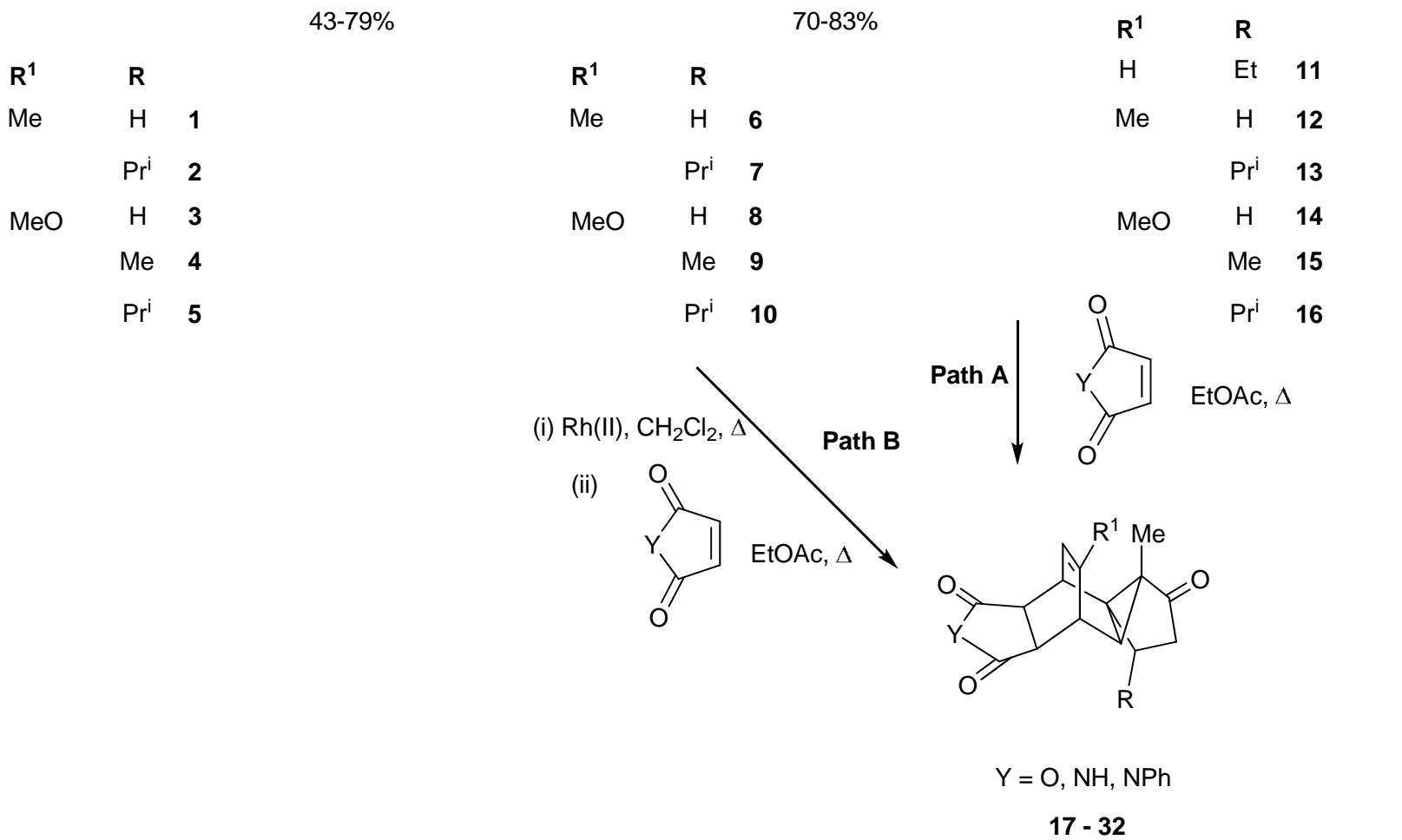

\section{Scheme 4}

Our initial studies concentrated on reaction of typical dienophiles (dimethyl acetylenedicarboxylate, maleimide, $N$-phenylmaleimide and maleic anhydride) with azulenone 11 which was unsubstituted at the 4, 5 or 6 positions, which had been previously employed in the PTAD cycloaddition. ${ }^{3 \mathrm{~b}}$ Despite extensive variation of the reaction conditions by varying factors such as solvent (toluene, dichloromethane and water), temperature (R.T. and reflux) and catalysis (Lewis acids) to promote the reaction there was no evidence for cycloaddition. To overcome this, activation of the NCD as diene through substitution of the aromatic ring of the precursor diazoketone with electron donating groups, such as methyl or methoxy, was explored.

Thus a series of $\alpha$-diazoketones 6-10 was synthesized bearing either a methyl or a methoxy group on the 4-position of the phenyl ring (Scheme 4). Each of the $\alpha$-diazoketones was readily prepared from the corresponding carboxylic acid via transformation to the acid chloride followed by treatment with excess ethereal diazoethane. Critically cyclisation of the para substituted aryl 
diazoketones can only provide a single regioisomer bearing the substituent at the 6-position which should lead to activation of the diene. These diazoketones were then cyclised using rhodium(II) acetate or rhodium(II) perfluorobutyrate as catalyst to provide the azulenones 12-16. The syntheses of the methoxy-substituted diazoketones 8 - 10 and azulenones 14-16 were described previously by our group. ${ }^{6}$

Formation of the trans isomer only was observed by ${ }^{1} \mathrm{H}$ NMR in the rhodium(II) acetate catalysed cyclisation of the 4-methyl-substituted diazoketone 7 (i.e. diastereoselectivity was typically $>98: 2$ trans:cis) which was in agreement with our previously published results on the diastereoselectivity of related aromatic addition reactions to unsubstituted phenyl rings. ${ }^{3}$

Table 1. Synthesis of cycloadducts 17-32

\begin{tabular}{|c|c|c|c|c|c|c|c|c|}
\hline $\mathrm{X}$ & $\mathrm{R}$ & $\begin{array}{l}\text { Diazo- } \\
\text { ketone }\end{array}$ & Azulenone & $\begin{array}{l}\text { Trans: } \\
\text { Cis }\end{array}$ & $\mathrm{Y}$ & Adduct & $\begin{array}{l}\% \text { Yield } \\
\text { Path A }\end{array}$ & $\begin{array}{l}\text { \%Yield } \\
\text { Path B }\end{array}$ \\
\hline $\mathrm{H}$ & Et & & 11 & $>98: 2$ & $\mathrm{O}^{\mathrm{b}}$ & 17 & 0 & \\
\hline \multirow[t]{3}{*}{$\mathrm{Me}$} & $\mathrm{H}$ & 6 & 12 & & $\mathrm{O}$ & 18 & & 45 \\
\hline & & & & & $\mathrm{NH}$ & 19 & & 30 \\
\hline & & & & & $\mathrm{NPh}$ & 20 & 52 & \\
\hline \multirow[t]{3}{*}{$\mathrm{Me}$} & $\operatorname{Pr}^{\mathrm{i}}$ & 7 & 13 & $>98: 2$ & $\mathrm{O}$ & 21 & 0 & \\
\hline & & & & $>98: 2$ & $\mathrm{NH}$ & 22 & 0 & \\
\hline & & & & $>98: 2$ & $\mathrm{NPh}$ & 23 & 0 & \\
\hline \multirow[t]{3}{*}{$\mathrm{OMe}$} & $\mathrm{H}$ & 8 & 14 & & $\mathrm{O}$ & 24 & 43 & 39 \\
\hline & & & & & $\mathrm{NH}$ & 25 & 65 & \\
\hline & & & & & $\mathrm{NPh}$ & 26 & 63 & 51 \\
\hline \multirow[t]{3}{*}{$\mathrm{OMe}$} & $\mathrm{Me}$ & 9 & 15 & & $\mathrm{O}$ & 27 & & 25 \\
\hline & & & & $80: 20$ & $\mathrm{NH}$ & 28 & $79^{c}$ & \\
\hline & & & & $82: 18$ & $\mathrm{NPh}$ & 29 & 45 & 49 \\
\hline \multirow[t]{3}{*}{$\mathrm{OMe}$} & $\operatorname{Pr}^{\mathrm{i}}$ & 10 & 16 & $90: 10$ & $\mathrm{O}$ & 30 & 45 & \\
\hline & & & & $80: 20$ & $\mathrm{NH}$ & 31 & 41 & \\
\hline & & & & $80: 20$ & $\mathrm{NPh}$ & 32 & 32 & \\
\hline
\end{tabular}

${ }^{a}$ The diastereomeric ratio of the azulenone was not measured when the reaction was conducted by this route.

${ }^{b}$ This reaction was conducted in toluene

${ }^{c}$ A minor diastereomer was formed in the ratio 7:93.

The 6-methyl-azulenone 12 was reacted successfully with maleic anhydride, maleimide and $N$-phenylmaleimide under reflux in ethyl acetate giving the adducts 18, 19 and 20 as white solids (Scheme 4, Table 1). Typically the cycloadditions were complete following heating under reflux overnight. 
Adducts could also be prepared directly from the diazoketone $\mathbf{6}$ in a pseudo-one pot reaction: the cyclization was conducted following the standard procedure by dropwise addition of the diazoketone to a dilute suspension of the catalyst in refluxing DCM, followed by evaporation of the dichloromethane from the crude azulenone 12, which was then redissolved in ethyl acetate with the dienophile and heated under reflux for $16 \mathrm{~h}$ to give the adducts 18 and 19 . Significantly these results confirmed that introduction of the methyl substituent was sufficiently activating to result in Diels-Alder cycloaddition under relatively mild conditions. Interestingly with the trans isopropyl-substituted azulenone 13, despite the presence of the activating methyl substituent on the diene, all attempts to effect cycloaddition with maleic anhydride, maleimide and $\mathrm{N}$ phenylmaleimide proved unsuccessful. Clearly, the presence of the isopropyl group on the lower face of the azulenone, opposite to the bridgehead methyl substituent which directs dienophile approach to the lower face, is sufficient to hinder approach of the dienophile to the diene in the NCD tautomer. Interestingly we have reported previously that azulenones bearing either an isopropyl or tert-butyl substituent at the 3-position will form adducts with the nitrogenous dienophile $\mathrm{PTAD}^{3 \mathrm{~b}}$ albeit at a slightly reduced rate compared to azulenones bearing less sterically demanding $n$-alkyl substituents at this position. This observation serves to highlight the difference in reactivity between the carbon- and nitrogen-based dienophiles.

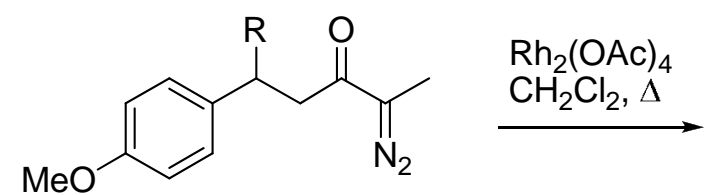<smiles>[R]C1CC(=O)[C@]2(C)C=CC(OC)=CC=C1C2=O</smiles>
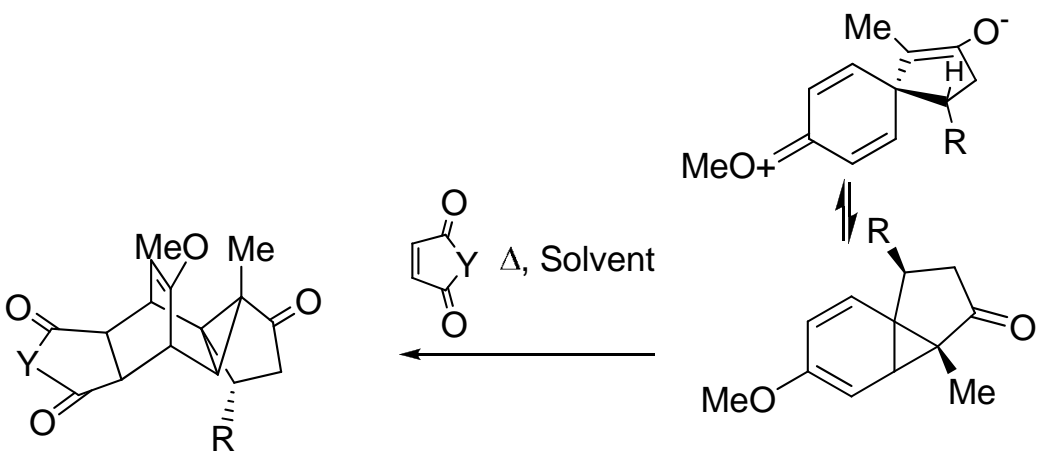

$\mathrm{R}=\mathrm{H} 14$, Me 15, Pri 16

$\mathrm{R}=\mathrm{H}, \quad \mathrm{Y}=\mathrm{O}, 24 ; \mathrm{NH}, 25 ; \mathrm{NPh}, 26$

$\mathrm{R}=\mathrm{Me}, \mathrm{Y}=\mathrm{O}, 27 ; \mathrm{NH}, 28 ; \mathrm{NPh}, 29$

$\mathrm{R}=$ Pri, $\mathrm{Y}=\mathrm{O}, \mathbf{3 0} ; \mathrm{NH}, \mathbf{3 1} ; \mathrm{NPh}, 32$

\section{Scheme 5}

The impact of methoxy substitution on the cycloaddition was next explored, employing azulenones 14 - 16 bearing the strongly activating methoxy group at the 6-position on the azulenone. At the outset we wished to explore whether the enhanced activation associated with 
alkoxy, relative to alkyl, substituent would overcome the steric effect of the 3-substituent seen with 13. However, it quickly became apparent that the presence of the 6-methoxy substituent leads to more complex dynamic behaviour in the azulenones 14-16 with interconversion between the cis and trans diastereomers of the azulenones $\mathbf{1 5}$ and $\mathbf{1 6}$ observed (Scheme 5). ${ }^{6}$ Indeed, the cycloadduct formation discussed below proved key to understanding the dynamic properties of these complex azulenones.

Critical to the success of this study was the existence of the equilibrium illustrated in Scheme 5. ${ }^{6}$ Thus in addition to the NCD-CHT interconversion the presence of the 6-methoxy substituent enables interconversion of the trans and cis diastereomers through a spiro intermediate. Though this particular equilibrium process was novel there is a precedent for the involvement of a methoxy substituent in the cleavage of norcaradiene in reactions described by Mander. ${ }^{7}$

Diene activation via methoxy substitution proved to be very effective. Initially the unsubstituted azulenone $\mathbf{1 4}$ was reacted successfully with a variety of dienophiles and generally the reactivity was higher than that observed for the analogous methyl-substituted azulenone $\mathbf{1 2}$ and resulted in higher yields (Table 1). The reaction of $\mathbf{1 4}$ with maleic anhydride was used to examine the effect of variation of temperature and solvent on the outcome of the reaction. The cycloaddition was found to proceed poorly, if at all, at room temperature and product was only detected in $>10 \%$ yield when the reaction was conducted at elevated temperature. Thermal effects were clearly seen: when the reaction was conducted in diethyl ether, no cycloaddition was detected, and in methanol and dichloromethane, the product, while formed, was not present in sufficient amounts to be isolated. The optimum conditions were found to be the use of either ethyl acetate or toluene as the solvent at reflux temperatures. In general, ethyl acetate was used in subsequent reactions as it proved easier to remove from the crude product and indeed some of the cycloadducts crystallized directly from this solvent. The concentration of azulenone employed was typically $\sim 0.1 \mathrm{~mol} \mathrm{dm}^{-3}$.

The 3-methyl- and 3-iso-propyl-substituted azulenones $\mathbf{1 5}$ and $\mathbf{1 6}$ also successfully reacted with all three dienophiles. At the outset of this work we were not aware of the existence of the cis - trans equilibrium in these systems, and, as the azulenones initially consisted of an 80:20 mixture trans:cis isomers of $\mathbf{1 5}$ and 16, it was assumed that isolation of the cycloadducts as single diastereomers in typically $25-45 \%$ yields meant that the cycloadducts derived from the major trans isomer of the azulenones had been isolated. In just one case, cycloadduct 28, was there evidence for formation of a minor amount of a second diastereomer. Initial interpretation that the increased activation associated with the methoxy substituent overcame the steric hindrance of the 3-isopropyl substituent which had been seen with the methyl-substituted azulenone 13, was very quickly proved incorrect. Determination of the X-ray structure of the crystalline cycloadduct $\mathbf{2 9}$ unexpectedly indicated that the product of the reaction was derived from the minor cis diastereomer. As the yield obtained is substantially higher that the amount of the cis-azulenone $\mathbf{1 5}$ present in the starting material, this provided critical evidence for the equilibrium process (Scheme 5). 
Analysis of the results indicated that while the thermodynamically preferred diasteromer of the azulenones 15 and $\mathbf{1 6}$ has trans orientation of the bridgehead methyl and 3-substituent, this clearly is less amenable to cycloaddition than the minor cis isomer in which the bridgehead methyl and 3-substituent are on the same face, thereby leaving the $\alpha$-face open for dienophile approach. Therefore, while the methoxy substitution did lead to cycloaddition even in the presence of the 3-isopropyl substituent, this was not simply due to enhanced reactivity of the diene, but instead reflected the potential for isomerisation to the less sterically hindered cis isomer of the NCD. Notably, in the reaction of maleimide with the methyl-substituted azulenone 15 there was evidence for the formation of a second diastereomer of the cycloadduct presumably from the trans NCD diastereomer, but this has not been structurally confirmed. While the majority of the cycloadditions with the methoxy-substituted azulenones 14-16 were conducted on pure azulenones, two cycloadducts 24 and 29 were prepared using the pseudo one-pot process, in comparable yields and efficiency.

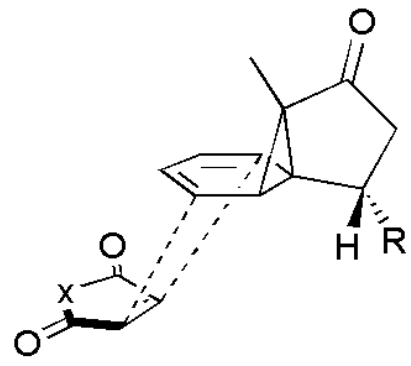

A

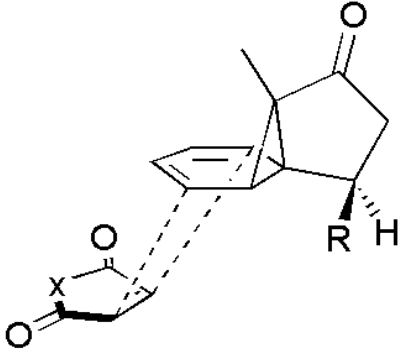

B

\section{Figure 1}

Evidently, approach of the dienophile to the cis isomers of the NCDs through transition state A (Fig. 1) is easier with than in the trans isomers in which the alkyl substituent $\mathrm{R}$ hinders the approach of the dienophile as depicted in transition state B. This explains why the azulenones $\mathbf{1 1}$ and 13 which were available only as the trans isomer did not react to form an adduct. Only those azulenones that are unsubstituted at the 3 position (Scheme 2), and those azulenones in which the cis isomer is accessible (through the equilibrium process described) undergo cycloaddition under the conditions explored.

In combining the two steps of aromatic addition and cycloaddition we have converted a relatively simple and accessible compound with one stereogenic centre, to a complex carbocyclic framework with eight stereogenic centers with complete diastereocontrol. These cycloadducts have a number of interesting features which may be exploited further, namely the enol ether and cyclopropyl ketone as well as the dienophile residue. 


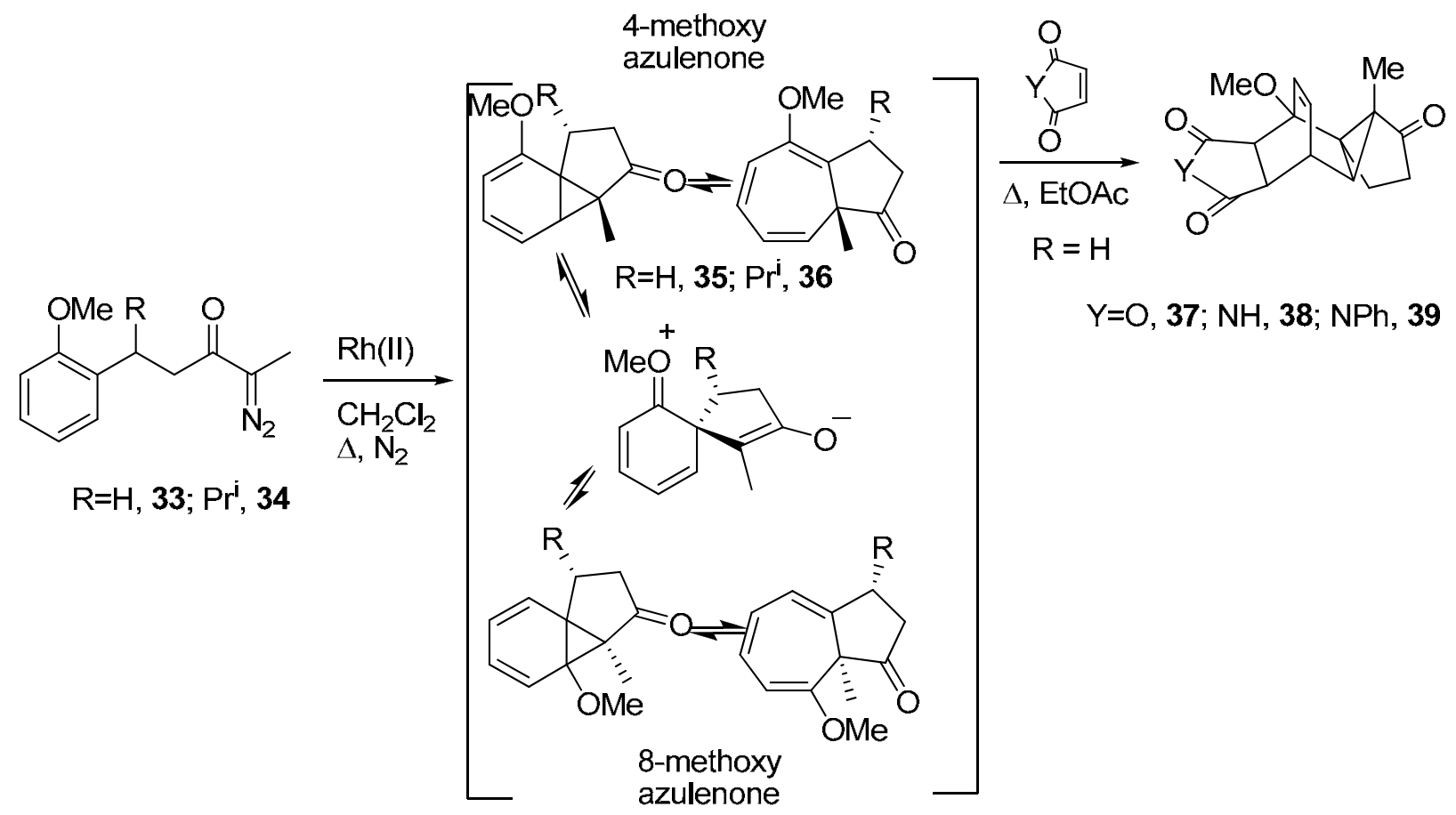

\section{Scheme 6}

To confirm the existence of the dynamic equilibrium between the cis and trans isomers of the 6-methoxy-substituted azulenones, the reactivity of 4-methoxy azulenones was next explored. Similar behavior in this system should result in interconversion of regioisomers rather than diastereomers as illustrated in Scheme 6. The 2'-methoxy-substituted aryl diazoketones 33 and 34 were prepared and cyclised using rhodium acetate or perfluorobutyrate to give a mixture of azulenones bearing the methoxy substituent at the 4 and 8 positions respectively with the kinetic product being the 4-substituted azulenones 35 and $36 .{ }^{6}$ Following the mechanistic rationale developed earlier, the isopropyl-substituted azulenone $\mathbf{3 6}$ was formed stereoselectively with only the trans isomer of the 4-methoxy azulenone and accordingly only the cis isomer of the 8methoxy azulenone detected. 
Table 2. Results for the synthesis of adducts derived from ortho-methoxy-substituted diazoketones

\begin{tabular}{llllllll}
\hline $\mathrm{R}$ & $\begin{array}{l}\text { Diazo- } \\
\text { ketone }\end{array}$ & Azulenone & 4-MeO:8-Meo & $\mathrm{Y}$ & Adduct & $\begin{array}{l}\text { \% Yield } \\
\text { Path A }^{\mathrm{a}}\end{array}$ & $\begin{array}{l}\text { \%Yield } \\
\text { Path B }\end{array}$ \\
\hline $\mathrm{H}$ & $\mathbf{3 3}$ & $\mathbf{3 5}$ & $90: 10$ & $\mathrm{O}$ & $\mathbf{3 7}$ & & 60 \\
& & & & $\mathrm{NH}$ & $\mathbf{3 8}$ & & $63^{\mathrm{b}}$ \\
& & \multirow{3}{*}{$\mathbf{3}$} & $63: 37$ & $\mathrm{NPh}$ & $\mathbf{3 9}$ & 61 & $57^{\mathrm{b}}$ \\
$\operatorname{Pr}^{\mathrm{i}}$ & $\mathbf{3 4}$ & \multirow{3}{*}{} & $80: 20$ & $\mathrm{O}$ & & & 0 \\
& & $80: 20$ & $\mathrm{NH}$ & & & 0 \\
& & $80: 20$ & $\mathrm{NPh}$ & & \\
\hline
\end{tabular}

${ }^{a}$ This reaction was conducted with purified azulenone

${ }^{b}$ The diastereomeric ratio of the azulenone was not measured when the reaction was conducted by this route.

Diels-Alder cycloadditions of azulenone 35 unsubstituted at the 3-position proceeded efficiently, resulting in a single cycloadduct in each case derived from reaction of the NCD of the 4-methoxy azulenone (Table 2). In the isomeric 8-methoxy azulenone the diene moiety is not activated by the methoxy substituent (Scheme 6) and therefore cycloaddition to this isomer is not observed with the carbon based dienophiles. In most cases the diazoketones were transformed directly to the cycloadducts without isolation of the azulenone intermediate, although when cycloadduct 39 was prepared from isolated azulenone the outcome was comparable both in terms of yield and efficiency.

When the equivalent reactions were conducted with the iso-propyl-substituted azulenone $\mathbf{3 6}$ there was no evidence for cycloaddition with any of the three dienophiles under reflux in ethyl acetate. This can be explained by the fact that in this case the 4-methoxy compound has a trans relationship between the 3-isopropyl substituent and the bridgehead methyl group thereby rendering this unreactive towards cycloaddition. In this instance, the cis isomer is not accessible for the cycloaddition to occur (Scheme 6). While the 8-methoxy azulenone is formed through the dynamic equilibrium and has the cis relative stereochemistry, in this case cycloaddition does not proceed under the conditions explored as the diene in the NCD is no longer activated by the methoxy group.

\section{Conclusions}

Diels-Alder cycloadditions of azulenones, formed through intramolecular Buchner reaction of $\alpha$ diazoketones, with carbon based dienophiles proved successful provided the dienes were activated through methyl or methoxyl substitution on the diene. Reactivity was noticeably reduced relative to earlier studies with PTAD as dienophile. Cycloaddition to the NCD tautomer 
only was observed in all cases. Complete diastereocontrol in the formation of the polycyclic frameworks containing eight stereogenic centres based on the single stereocentre present in the diazoketone precursor was obtained. The two reactions - aromatic addition and cycloaddition can be conducted in a pseudo-one pot fashion. Further investigation of the reactivity of these rigid polycyclic systems will be reported in due course.

\section{Experimental Section}

General Procedures. All reactions were conducted under an inert nitrogen atmosphere. ${ }^{1} \mathrm{H}$ $(270 \mathrm{MHz})$ and ${ }^{13} \mathrm{C}(67.8 \mathrm{MHz})$ NMR spectra were recorded on a Jeol GSX $270 \mathrm{NMR}$ spectrometer. All spectra were recorded at room temperature $(\sim 20 \circ \mathrm{C})$ in deuterated chloroform $\left(\mathrm{CDCl}_{3}\right)$ unless otherwise stated. Chemical shifts $(\delta)$ are quoted in parts per million (ppm) downfield from tetramethylsilane and coupling constants $(J)$ in Hertz $(\mathrm{Hz}) .{ }^{13} \mathrm{C}$ NMR spectra were assigned with the aid of DEPT experiments.

Elemental analyses were performed on a Perkin-Elmer 240 elemental analyzer. Mass spectra were recorded on a Kratos Profile HV-4 double focusing high resolution mass spectrometer (E.I). Thin layer chromatography (TLC) was carried out on precoated silica gel plates (Merck 60 $\mathrm{PF}_{254}$ ). Melting points are uncorrected. All solvents were dried and distilled prior to use. Organic phases were dried using anhydrous magnesium sulfate.

We have reported the synthesis of diazoketones 8-10, 33 and 34 and azulenones 11, 14-16, 35, and 36 previously. ${ }^{3 b, 6}$

2-Diazo-5-(4-methylphenyl)pentan-3-one (6). Oxalyl chloride (1.09 mL, $\left.1.25 \times 10^{-2} \mathrm{~mol}\right)$ was added dropwise over $5 \mathrm{~min}$ to 3-(4-methylphenyl)propanoic acid (1.02 g, $\left.6.22 \times 10^{-3} \mathrm{~mol}\right)$ in dry ether $(40 \mathrm{~mL})$, while stirring at $0{ }^{\circ} \mathrm{C}$ under nitrogen. The solution was allowed to slowly return to room temperature while stirring for $18 \mathrm{~h}$. The solvent and residual reagent was removed under reduced pressure to give the acyl chloride which was used without further purification. An etheral diazoethane solution ${ }^{8}$ was prepared from $N$-ethyl- $N$-nitrosourea $\left(7.14 \mathrm{~g}, 6.10 \mathrm{x} 10^{-2} \mathrm{~mol}\right)$, ether $(60 \mathrm{~mL})$ and aqueous potassium hydroxide $(50 \%, 25 \mathrm{~mL})$ according to the procedure described by $\mathrm{Arndt}^{8}$ and cooled to $-20{ }^{\circ} \mathrm{C}$ using a salt-ice bath. The crude acyl chloride in dry ether $(20 \mathrm{ml})$ was added dropwise over $20 \mathrm{~min}$ to the stirring diazoethane solution under nitrogen. The solution was then allowed to return to room temperature while stirring for $4 \mathrm{~h}$. The ether and residual diazoethane were evaporated under reduced pressure on a rotary evaporator fitted with an acetic acid trap. Purification by chromatography on silica gel, using ethyl acetatehexane (5:95) as eluant, gave the diazoketone $6(0.83 \mathrm{~g}, 66 \%)$ as a yellow oil; found: $\mathrm{C}, 71.21$; $\mathrm{H}, 7.05 ; \mathrm{N}, 14.15 \% \mathrm{C}_{12} \mathrm{H}_{14} \mathrm{~N}_{2} \mathrm{O}$ requires $\mathrm{C}, 71.26 ; \mathrm{H}, 6.98 ; \mathrm{N}, 13.85 \%$. $v_{\max }$ (film) 2069,1634 , $1516 \mathrm{~cm}^{-1} ; \delta_{\mathrm{H} .}\left(\mathrm{CDCl}_{3}\right) 1.93\left[3 \mathrm{H}\right.$, br s, C $\left.(1) H_{3}\right], 2.31\left[3 \mathrm{H}, \mathrm{s}, \mathrm{C}\left(4^{\prime}\right) \mathrm{CH}_{3}\right], 2.63-2.82$ [2H, br m, $\mathrm{C}(4) H_{2}$ ], 2.87-3.01 [2H, m, C(5)H $H_{2}$, 7.03-7.19 (4H, m, $\left.\mathrm{ArH}\right) ; \delta_{\mathrm{C}}\left(\mathrm{CDCl}_{3}\right) 8.1(\mathrm{Me}), 21.0(\mathrm{Me})$, 30.4, 39.7 (2 x CH 2$), 62.3(\mathrm{C}), 128.3(\mathrm{CH}), 129.2(\mathrm{CH}), 135.8(\mathrm{C}), 137.7(\mathrm{C}), 194.7(\mathrm{C}) ; m / z(\mathrm{EI})$ 
found: 202.1087. $\mathrm{C}_{12} \mathrm{H}_{14} \mathrm{O}$ requires ${\mathrm{M}-\mathrm{N}_{2}}^{+}$202.1106; 204 (7\%), 202 (4\%), 187 (15\%), 147 (13\%), $118(60 \%), 105(100 \%), 91$ (13\%).

2-Diazo-5-(4-methylphenyl)-6-methylheptan-3-one (7). This was prepared following the procedure described for 6 using 3-(4-methylphenyl)-4-methylpentanoic acid $\left(2.50 \mathrm{~g}, 1.21 \times 10^{-2}\right.$ mol) in dry ether $(50 \mathrm{~mL})$, oxalyl chloride $\left(2.20 \mathrm{~mL}, 2.52 \times 10^{-2} \mathrm{~mol}\right)$ and freshly distilled ethereal diazoethane [prepared from $N$-ethyl- $N$-nitrosourea $\left(10.99 \mathrm{~g}, 9.39 \times 10^{-2} \mathrm{~mol}\right)$, ether $(70 \mathrm{~mL})$ and $\left.\mathrm{KOH}(50 \% \text { aqueous solution, } 31 \mathrm{~mL})^{8}\right]$. Purification by chromatography on silica gel, using ethyl acetate-hexane (5:95) as eluant, gave the diazoketone $7(1.45 \mathrm{~g}, 49 \%)$ as a yellow oil; found: $\mathrm{C}, 74.09 ; \mathrm{H}, 8.51 ; \mathrm{N}, 10.29 \% \mathrm{C}_{15} \mathrm{H}_{20} \mathrm{~N}_{2} \mathrm{O}$ requires $\mathrm{C}, 73.74 ; \mathrm{H}, 8.25 ; \mathrm{N}$, $11.46 \%$ ); $v_{\max }$ (film) 2070,1636, $1514 \mathrm{~cm}^{-1} ; \delta_{\mathrm{H}}\left(\mathrm{CDCl}_{3}\right) 0.74\left[3 \mathrm{H}, \mathrm{d}, J 7\right.$, one of $\mathrm{C}(6) \mathrm{CH}_{3}$ or $\mathrm{C}(7) H_{3}$ ], 0.95 [3H, d, $J 6$, one of $\mathrm{C}(6) \mathrm{CH}_{3}$ or $\mathrm{C}(7) H_{3}$ ], $1.69-2.03$ [4H m containing $3 \mathrm{H}$ s at 1.78 for $\left.\mathrm{C}(1) H_{3}, \mathrm{C}(6) H\right], 2.31\left[3 \mathrm{H}, \mathrm{s}, \mathrm{C}\left(4^{\prime}\right) \mathrm{CH}_{3}\right], 2.69-2.86$ [2H, br m, C(4)H $\left.H_{2}\right], 2.87-3.00[1 \mathrm{H}, \mathrm{m}$, $\mathrm{C}(5) H]$, 6.97-7.16 (4H, m ArH); $\delta_{\mathrm{C}}\left(\mathrm{CDCl}_{3}\right) 8.0(\mathrm{Me}), 20.5(\mathrm{Me}), 20.7(\mathrm{Me}), 20.8(\mathrm{Me}), 32.9$ $(\mathrm{CH}), 41.6,47.8\left(\mathrm{CH}, \mathrm{CH}_{2}\right), 62.4(\mathrm{C}), 128.8(\mathrm{CH}), 128.3(\mathrm{CH}), 135.7(\mathrm{C}), 139.9(\mathrm{C}), 193.7(\mathrm{C})$; $\mathrm{m} / \mathrm{z}(\mathrm{EI}) 216\left(\mathrm{M}^{+}-\mathrm{N}_{2}, 28 \%\right), 201(3 \%), 173(37 \%), 146(37 \%), 131$ (7\%), $105(44 \%)$.

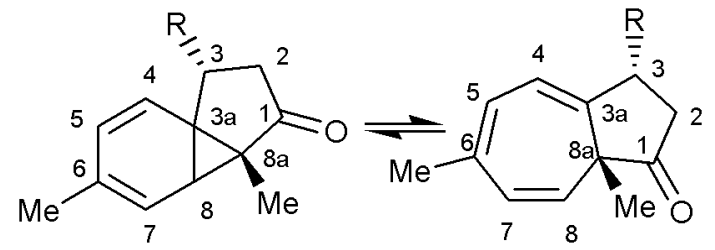

Figure 2. Numbering system for azulenone products.

6,8a-Dihydro-6,8a-dimethylazulen-1(2H)-one (12). A solution of 2-diazo-5-(4methylphenyl)pentan-3-one $6\left(100 \mathrm{mg}, 4.95 \times 10^{-4} \mathrm{~mol}\right)$ in dichloromethane $(100 \mathrm{~mL})$ was added dropwise over $1 \mathrm{~h}$ to a stirring refluxing solution of rhodium(II) perfluorobutyrate $(0.5 \mathrm{mg})$ in dichloromethane $(100 \mathrm{~mL})$. When the addition was finished TLC analysis confirmed reaction completion. The solvent was removed in vacuo. A ${ }^{1} \mathrm{H}$ NMR spectrum of the crude product was recorded to determine the efficiency of the cyclisation (88\%) (by integration of the ${ }^{1} \mathrm{H}$ NMR spectrum). Purification by column chromatography on silica gel, using gradient ethyl acetatehexane as eluant, gave the azulenone $12\left(71 \mathrm{mg}, 82 \%\right.$ ) as a colourless oil; $v_{\max }$ (film) 1746, $1713,1448 \mathrm{~cm}^{-1} ; \delta_{\mathrm{H}}\left(\mathrm{CDCl}_{3}\right) 0.72\left[3 \mathrm{H}, \mathrm{s}, \mathrm{C}(8 \mathrm{a}) \mathrm{CH}_{3}\right], 1.95\left[3 \mathrm{H}, \mathrm{s}, \mathrm{C}(6) \mathrm{CH}_{3}\right], 2.24-2.58[4 \mathrm{H}, \mathrm{m}$, $\left.\mathrm{C}(2) H_{2}, \mathrm{C}(3) H_{2}\right], 3.61[1 \mathrm{H}, \mathrm{d}, J 6.9, \mathrm{C}(8) H], 5.83[1 \mathrm{H}, \mathrm{d}, J 7.3, \mathrm{C}(7) H], 6.01-6.16[2 \mathrm{H}, \mathrm{ABq}, J 8$, $\mathrm{C}(5) H, \mathrm{C}(4) H] ; \delta_{\mathrm{C}}\left(\mathrm{CDCl}_{3}\right) 10.1(\mathrm{Me}), 22.7(\mathrm{Me}), 27.2,34.0\left(2 \times \mathrm{CH}_{2}\right), 37.0(\mathrm{C}), 76.5(\mathrm{CH}$, broad), 86.5 (C), 123.7, 124.4, 126.7 (3 x CH), 135.0 (C), 219.0 (C). trans-(3R*,8aS*)-3,8a-Dihydro-3-i-propyl-6,8a-dimethylazulen-1(2H)-one (trans-13) cis-(3R*,8aR*)-3,8a-Dihydro-3-i-propyl-6,8a-dimethylazulen-1(2H)-one (cis-13). These were prepared following the procedure described for 12, from 2-diazo-5-(4-methylphenyl)-4methylheptan-3-one $7\left(100 \mathrm{mg}, 4.10 \times 10^{-4} \mathrm{~mol}\right)$ in dichloromethane $(100 \mathrm{~mL})$ and using rhodium(II) acetate $(0.5 \mathrm{mg})$ as catalyst, in dichloromethane $(100 \mathrm{ml})$. A ${ }^{1} \mathrm{H}$ NMR spectrum of 
the crude product was recorded to determine the efficiency of the cyclisation (74\%) and the diastereomeric ratio of the azulenones formed: diastereomeric ratio, trans 13:cis 13, >98:2 [by comparison of the ${ }^{1} \mathrm{H}$ NMR integration for $\mathrm{C}(8) H$ cis and trans, i.e. cis azulenone not seen]. Purification by column chromatography on silica gel, using gradient ethyl acetate-hexane as eluant, gave a single diastereomer of the azulenone trans $\mathbf{1 3}(62 \mathrm{mg}, 70 \%)$ as a colourless oil; $v_{\max }$ (film) $1745,1713 \mathrm{~cm}^{-1} ; \delta_{\mathrm{H}}\left(\mathrm{CDCl}_{3}\right) 0.67\left[3 \mathrm{H}, \mathrm{s}, \mathrm{C}(8 \mathrm{a}) \mathrm{CH}_{3}\right], 0.80\left[3 \mathrm{H}, \mathrm{d}, J 7\right.$, one $\mathrm{CH}_{3}$ of $\mathrm{CH}\left(\mathrm{CH}_{3}\right)_{2}$ ], 0.89 [3H, d, $J$ 7, one $\mathrm{CH}_{3}$ of $\left.\mathrm{CH}\left(\mathrm{CH}_{3}\right)_{2}\right], 1.55-1.74\left[1 \mathrm{H}, \mathrm{m}, \mathrm{CH}\left(\mathrm{CH}_{3}\right)_{2}\right], 1.90-2.07$ [4H, m, containing s at 1.93 for $\mathrm{C}(6) \mathrm{CH}_{3}$, one of $\left.\mathrm{C}(2) \mathrm{H}_{2}\right], 2.35-2.61[2 \mathrm{H}, \mathrm{m}, \mathrm{C}(3) \mathrm{H}$, one of $\left.\mathrm{C}(2) H_{2}\right], 3.36[1 \mathrm{H}, \mathrm{d}, J 7.0, \mathrm{C}(8) H], 5.78[1 \mathrm{H}, \mathrm{d}, J 6, \mathrm{C}(7) H], 5.98-6.13[2 \mathrm{H}, \mathrm{m}, \mathrm{C}(4) H, \mathrm{C}(5) H]$; $\delta_{\mathrm{C}}\left(\mathrm{CDCl}_{3}\right) 8.7(\mathrm{Me}), 19.6(\mathrm{Me}), 21.0(\mathrm{Me}), 22.4(\mathrm{Me}), 29.7(\mathrm{C}), 32.3(\mathrm{CH}), 37.9\left(\mathrm{CH}_{2}\right), 46.0$ $(\mathrm{CH}), 64.4$ (CH, broad), 121.8, 126.2, $126.4(3 \times \mathrm{CH}), 135.0$ (C) 218.1 (C). C-3a not detected; $\mathrm{m} / \mathrm{z}$ (EI) found 216.1515. $\mathrm{C}_{15} \mathrm{H}_{20} \mathrm{O}$ requires $\mathrm{M}^{+} 216.1514 ; 216$ (56\%), 201 (17\%), 173 (26\%), $146(100 \%), 145$ (93\%), $128(33 \%), 118(58 \%)$.

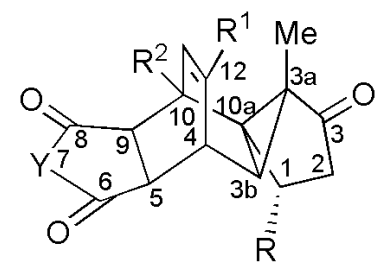

Figure 3. Numbering system for adducts prepared in this study.

Adduct 18. (a) One pot preparation of adduct 18 from maleic anhydride and 2-diazo-5-(4methylphenyl)pentan-3-one $\mathbf{6}$.

The azulenone was prepared as follows: 2-diazo-5-(4-methylphenyl)pentan-3-one 6 (157 mg, $\left.7.79 \times 10^{-4} \mathrm{~mol}\right)$ in dichloromethane $(100 \mathrm{~mL})$ was added over $1 \mathrm{~h}$ to a stirring refluxing solution of rhodium(II) acetate $(0.5 \mathrm{mg})$ as catalyst, in dichloromethane $(100 \mathrm{~mL})$. The reaction was complete by TLC on completion of addition of the diazoketone. The reaction mixture was cooled to room temperature and the solvent removed under reduced pressure to yield the crude azulenone 12. Maleic anhydride $\left(76 \mathrm{mg}, 7.79 \times 10^{-4} \mathrm{~mol}\right)$ was added to the crude azulenone in ethyl acetate $(5 \mathrm{~mL})$ ) which was then refluxed under nitrogen for $16 \mathrm{~h}$. TLC analysis at this stage indicated the absence of the azulenone. The solution was cooled to room temperature and the solvent removed under reduced pressure. Excess dienophile and aromatic impurities were removed by trituration with ether to yield the adduct $18(95.5 \mathrm{mg}, 45 \%)$ as a colorless solid, $\mathrm{mp}$ 173-176 ${ }^{\circ} \mathrm{C}$; found $\mathrm{C}, 70.34 ; \mathrm{H}, 6.10 \% \mathrm{C}_{16} \mathrm{H}_{16} \mathrm{O}_{4}$ requires $\mathrm{C}, 70.58 ; \mathrm{H}, 5.92 \%$; $v_{\max }(\mathrm{KBr}) 1776$, $1717 \mathrm{~cm}^{-1} ; \delta_{\mathrm{H}}\left(270 \mathrm{MHz} ; \mathrm{CDCl}_{3}\right) 1.09-1.28\left[4 \mathrm{H}, \mathrm{m}\right.$, containing $3 \mathrm{H} \mathrm{s}$ at 1.19 for $\mathrm{C}(3 \mathrm{a}) \mathrm{CH}_{3}$, $\mathrm{C}(3 \mathrm{~b}) H], 1.79\left[3 \mathrm{H}, \mathrm{s}, \mathrm{C}(12) \mathrm{CH}_{3}\right.$ ], $2.00-2.34$ [4H, m, C(2)H $\left.H_{2}, \mathrm{C}(3) H_{2}\right], 3.32-3.62$ [4H, m, C(4)H, $\mathrm{C}(5) H, \mathrm{C}(9) H, \mathrm{C}(10) H], 5.76[1 \mathrm{H}, \mathrm{br} \mathrm{d}, J 8, \mathrm{C}(11) H] ; \delta_{\mathrm{C}}\left(67.8 \mathrm{MHz} ; \mathrm{CDCl}_{3}\right) 9.8(\mathrm{Me}), 21.8$ $(\mathrm{Me}), 24.7\left(\mathrm{CH}_{2}\right), 30.4(\mathrm{CH}), 33.2\left(\mathrm{CH}_{2}\right), 38.5(\mathrm{CH}), 39.3(\mathrm{CH}), 39.8(\mathrm{C}), 40.9(\mathrm{C}), 44.9(\mathrm{CH})$, 
46.1(CH), 124.3(CH), $140.8(\mathrm{C}), 170.8(\mathrm{C}), 172.0(\mathrm{C}), 213.8(\mathrm{C}) ; \mathrm{m} / z(\mathrm{EI})$ found 272.1041. $\mathrm{C}_{16} \mathrm{H}_{16} \mathrm{O}_{4}$ requires $\mathrm{M}^{+}$272.1049); 272 (36), 199 (38), 174 (89), 132 (100), 115 (50), 91 (51).

Adduct 19. (a) One pot preparation of adduct 19 from maleimide and 2-diazo-5-(4methylphenyl)pentan-3-one $\mathbf{6}$.

This was prepared following the procedure described for 18, from 2-diazo-5-(4methylphenyl)pentan-3-one 6 (143 mg, $\left.7.08 \times 10^{-4} \mathrm{~mol}\right)$ in dichloromethane $(100 \mathrm{~mL})$ and rhodium acetate $(0.5 \mathrm{mg})$ in dichloromethane $(100 \mathrm{~mL})$ to give the crude azulenone 12 . Maleimide (69 mg, $\left.7.08 \times 10^{-4} \mathrm{~mol}\right)$ was added to the crude azulenone in ethyl acetate $(5 \mathrm{~mL})$ and the procedure described for $\mathbf{1 8}$ followed. Recrystallization from hexane-dichloromethane gave the adduct $19(58 \mathrm{mg}, 30 \%)$ as a colorless solid, $\mathrm{mp} 165-168{ }^{\circ} \mathrm{C} ; v_{\max }(\mathrm{KBr}) 2600-3400$, $1714 \mathrm{~cm}^{-1} ; \delta_{\mathrm{H}}\left(270 \mathrm{MHz} ; \mathrm{CDCl}_{3}\right)$ 1.15-1.79 [4H, m, containing $3 \mathrm{H} \mathrm{s}$ at 1.28 for $\mathrm{C}(3 \mathrm{a}) \mathrm{CH}_{3}$, $\mathrm{C}(3 \mathrm{~b}) H], 1.74\left[3 \mathrm{H}, \mathrm{s}, \mathrm{C}(12) \mathrm{CH}_{3}\right], 2.02-2.34\left[4 \mathrm{H}, \mathrm{m}, \mathrm{C}(2) H_{2}, \mathrm{C}(3) H_{2}\right], 3.11[1 \mathrm{H}, \mathrm{dd}, J 7,3$, one of $\mathrm{C}(5) H, \mathrm{C}(9) H], 3.26-3.39$ [2H, m, two of $\mathrm{C}(4) H, \mathrm{C}(5) H, \mathrm{C}(9) H, \mathrm{C}(10) H], 3.44[1 \mathrm{H}, \mathrm{dd}, J 9$, 4, one of $\mathrm{C}(4) H, \mathrm{C}(5) H, \mathrm{C}(9) H, \mathrm{C}(10) H], 5.68[1 \mathrm{H}$, br d, $J 8, \mathrm{C}(11) H], 8.31-8.46[1 \mathrm{H}$, br s, N$\mathrm{H}] ; \delta_{\mathrm{C}}\left(67.8 \mathrm{MHz} ; \mathrm{CDCl}_{3}\right) 10.0(\mathrm{Me}), 21.8(\mathrm{Me}), 24.9\left(\mathrm{CH}_{2}\right), 31.1(\mathrm{CH}), 32.3\left(\mathrm{CH}_{2}\right), 38.2(\mathrm{CH})$, $39.2(\mathrm{CH}), 39.9(\mathrm{C}), 41.4(\mathrm{C}), 45.6(\mathrm{CH}), 46.7(\mathrm{CH}), 123.5(\mathrm{CH}), 139.7(\mathrm{C}), 176.9(\mathrm{C}), 178.0$ (C), $214.5(\mathrm{C}) ; \mathrm{m} / \mathrm{z}(\mathrm{EI})$ found 271.1198. $\mathrm{C}_{16} \mathrm{H}_{17} \mathrm{NO}_{3}$ requires $\mathrm{M}+271.1208 ; 271$ (67\%), 256 (10), 174 (100), 132 (93).

Adduct 20. (a) Reaction of purified 3,8a-dihydro-6,8a-dimethylazulen-1(2H)-one 12 with $\mathrm{N}$ phenylmaleimide.

A solution of 3,8a-dihydro-6,8a-dimethylazulen-1(2H)-one $12\left(110 \mathrm{mg}, 6.32 \times 10^{-4} \mathrm{~mol}\right)$ and $\mathrm{N}$ phenylmaleimide $\left(110 \mathrm{mg}, 6.32 \times 10^{-4} \mathrm{~mol}\right)$ in ethyl acetate $(5 \mathrm{~mL})$ was refluxed under nitrogen for $16 \mathrm{~h}$. TLC analysis at this stage indicated the absence of the azulenone. The solution was cooled to room temperature and the solvent removed under reduced pressure. Excess dienophile and aromatic impurities were removed by trituration with ether. Recrystallization from ethanoldichloromethane gave the adduct 20 (114 mg, 52\%) as a colorless solid, mp 156-158 ${ }^{\circ} \mathrm{C}$; found C, 76.05; H, 6.21; N, 4.16\% $\mathrm{C}_{22} \mathrm{H}_{21} \mathrm{NO}_{3}$ requires $\mathrm{C}$, 76.06; H, 6.04; N, 4.03\%; $v_{\max }(\mathrm{KBr}) 1775$ (w), $1709 \mathrm{~cm}^{-1} ; \delta_{\mathrm{H}}\left(270 \mathrm{MHz} ; \mathrm{CDCl}_{3}\right) 1.21\left[3 \mathrm{H}, \mathrm{s}, \mathrm{C}(3 \mathrm{a}) \mathrm{CH}_{3}\right], 1.24[1 \mathrm{H}, \mathrm{d}, J 4, \mathrm{C}(3 \mathrm{~b}) H], 1.79$ $\left[3 \mathrm{H}, \mathrm{s}, \mathrm{C}(12) \mathrm{CH}_{3}\right], 2.02-2.35\left[4 \mathrm{H}, \mathrm{m}, \mathrm{C}(2) H_{2}, \mathrm{C}(3) H_{2}\right], 3.22[1 \mathrm{H}, \mathrm{dd}, J 8,4$, one of $\mathrm{C}(5) H$, $\mathrm{C}(9) H$ ], 3.38-3.47 [2H, m, two of $\mathrm{C}(4) H, \mathrm{C}(5) H, \mathrm{C}(9) H, \mathrm{C}(10) H], 3.43[1 \mathrm{H}, \mathrm{dd}, J 6$, 3, one of $\mathrm{C}(4) H, \mathrm{C}(5) H, \mathrm{C}(9) H, \mathrm{C}(10) H], 5.73$ [1H, br d, $J 8, \mathrm{C}(11) H], 7.07-7.17(2 \mathrm{H}, \mathrm{m}, \mathrm{Ar} H), 7.33-7.52$ $(3 \mathrm{H}, \mathrm{m}, \mathrm{ArH}) ; \delta_{\mathrm{C}}\left(67.8 \mathrm{MHz} ; \mathrm{CDCl}_{3}\right) 10.0(\mathrm{Me}), 21.7(\mathrm{Me}), 24.9\left(\mathrm{CH}_{2}\right), 31.2(\mathrm{CH}), 33.3\left(\mathrm{CH}_{2}\right)$, $38.8(\mathrm{CH}), 39.6(\mathrm{C}), 39.7(\mathrm{CH}), 41.5(\mathrm{C}), 44.4(\mathrm{CH}), 45.2(\mathrm{CH}), 123.6(\mathrm{CH}), 126.4(\mathrm{CH}), 128.7$ $(\mathrm{CH}), 129.1(\mathrm{CH}), 131.7(\mathrm{C}), 139.7(\mathrm{C}), 176.1(\mathrm{C}), 177.2(\mathrm{C}), 214.4(\mathrm{C}) ; \mathrm{m} / \mathrm{z}$ (EI) found 347.1524. $\mathrm{C}_{22} \mathrm{H}_{21} \mathrm{NO}_{3}$ requires $\mathrm{M}^{+}$347.1521; 347 (77\%), 332 (8), 174 (100), 132 (96), 173 (47), 117 (54), 91 (78).

Adduct 24. (a) Reaction of purified 3,8a-dihydro-6-methoxy-8a-methylazulen-1(2H)-one 14 with maleic anhydride.

This was prepared following the procedure described for 20, from 3,8a-dihydro-6-methoxy-8amethylazulen-1(2H)-one $14\left(147 \mathrm{mg}, 7.74 \times 10^{-4} \mathrm{~mol}\right)$ and maleic anhydride (76 mg, $7.76 \times 10^{-4}$ 
mol) in ethyl acetate $(5 \mathrm{~mL})$. Recrystallization from ethanol-dichloromethane gave the adduct $24(96 \mathrm{mg}, 43 \%)$ as a colorless solid, mp 205-206 ${ }^{\circ} \mathrm{C}$; found $\mathrm{C}, 66.71 ; \mathrm{H}, 5.61 \% \mathrm{C}_{16} \mathrm{H}_{16} \mathrm{O}_{5}$ requires $\mathrm{C}, 66.66 ; \mathrm{H}, 5.59 \% ; v_{\max }(\mathrm{KBr}) 1779,1722,1648 \mathrm{~cm}^{-1} ; \delta_{\mathrm{H}}\left(270 \mathrm{MHz} ; \mathrm{CDCl}_{3}\right) 1.13-1.28$ [4H, m, containing d, $J 4$ at 1.19 for $\mathrm{C}(3 \mathrm{~b}) \mathrm{H}$ and s at 1.22 for $\left.\mathrm{C}(3 \mathrm{a}) \mathrm{CH}_{3}\right], 2.03-2.38[4 \mathrm{H}, \mathrm{m}$, $\left.\mathrm{C}(1) \mathrm{H}_{2}, \mathrm{C}(2) \mathrm{H}_{2}\right], 3.35-3.52$ [5H, m, containing s at 3.48 for $\mathrm{OCH}_{3}$, two of $\mathrm{C}(4) \mathrm{H}, \mathrm{C}(5) \mathrm{H}, \mathrm{C}(9) \mathrm{H}$, $\mathrm{C}(10) H], 3.53-3.63[2 \mathrm{H}, \mathrm{m}$, two of $\mathrm{C}(4) H, \mathrm{C}(5) H, \mathrm{C}(9) H, \mathrm{C}(10) H], 4.72[1 \mathrm{H}, \mathrm{dd}, J 7,2$, $\mathrm{C}(11) H] ; \delta_{\mathrm{C}}\left(67.8 \mathrm{MHz} ; \mathrm{CDCl}_{3}\right) 8.5(\mathrm{Me}), 24.8\left(\mathrm{CH}_{2}\right), 29.1(\mathrm{CH}), 33.3\left(\mathrm{CH}_{2}\right), 37.7(\mathrm{CH}), 38.3$ $(\mathrm{CH}), 39.9(\mathrm{C}), 41.6(\mathrm{C}), 45.7(\mathrm{CH}), 46.1(\mathrm{CH}), 55.2(\mathrm{Me}), 92.8(\mathrm{CH}), 157.3(\mathrm{C}), 170.4(\mathrm{C})$, $171.8(\mathrm{C}), 213.2(\mathrm{C}) ; \mathrm{m} / z$ (EI) found 288.1004. $\mathrm{C}_{16} \mathrm{H}_{16} \mathrm{O}_{5}$ requires $\mathrm{M}^{+} 288.0998 ; 288(32 \%), 272$ (47), 260 (30), 215 (37), 165 (36), 147 (28), 134 (50), 121 (100), 109 (68).

(b) One pot preparation of adduct 24 from maleic anhydride and 2-diazo-5-(4'methoxyphenyl)pentan-3-one 8 .

This was prepared following the procedure described for 18, from 2-diazo-5-(4'methoxyphenyl)pentan-3-one $8\left(160 \mathrm{mg}, 7.34 \times 10^{-4} \mathrm{~mol}\right)$ in dichloromethane $(100 \mathrm{~mL})$ and rhodium acetate $(0.5 \mathrm{mg})$ in dichloromethane $(100 \mathrm{~mL})$ to give the crude azulenone 14. Maleic anhydride $\left(72 \mathrm{mg}, 7.35 \times 10^{-4} \mathrm{~mol}\right)$ was added to the crude azulenone in ethyl acetate $(5 \mathrm{~mL})$ and the procedure described for $\mathbf{1 8}$ followed. Recrystallization from ethanol-dichloromethane gave the adduct $24(82 \mathrm{mg}, 39 \%)$ as a colorless solid which had spectral characteristics which are the same as those described above.

Adduct 25. (a) Reaction of purified 3,8a-dihydro-6-methoxy-8a-methylazulen-1(2H)-one 14 with maleimide.

This was prepared following the procedure described for 20, from 3,8a-dihydro-6-methoxy-8amethylazulen-1(2H)-one $14\left(120 \mathrm{mg}, 6.29 \times 10^{-4} \mathrm{~mol}\right)$ and maleimide $\left(61 \mathrm{mg}, 6.32 \times 10^{-4} \mathrm{~mol}\right)$ in ethyl acetate $(5 \mathrm{~mL})$. Recrystallization from ethanol-dichloromethane gave the adduct 25 (118 mg, 65\%) as a colorless solid, mp 270-271 ${ }^{\circ} \mathrm{C}$; (Found C, 66.64; H, 5.73; N, 4.84\% $\mathrm{C}_{16} \mathrm{H}_{17} \mathrm{NO}_{4}$ requires $\mathrm{C}, 66.89 ; \mathrm{H}, 5.96 ; \mathrm{N}, 4.87 \%$. Found 287.1167. $\mathrm{C}_{16} \mathrm{H}_{17} \mathrm{NO}_{4}$ requires $\mathrm{M}^{+}$ 287.1158); $v_{\max }(\mathrm{KBr}) 3700-2700,1715,1651 \mathrm{~cm}^{-1} ; \delta_{\mathrm{H}}\left(270 \mathrm{MHz} ; \mathrm{CDCl}_{3}\right) 1.17[1 \mathrm{H}, \mathrm{d}, J 4$, $\mathrm{C}(3 \mathrm{~b}) H], 1.22$ [3H, s, C(3a)CH$H_{3}$ ], 2.01-2.37 [4H, m, C(1) $\left.H_{2}, \mathrm{C}(2) H_{2}\right], 3.12$ [1H, dd, $J 8$, 3, one of $\mathrm{C}(5) H, \mathrm{C}(9) H], 3.32[1 \mathrm{H}, \mathrm{dd}, J 8,3$, one of $\mathrm{C}(5) H, \mathrm{C}(9) H], 3.38-3.54[5 \mathrm{H}, \mathrm{m}$, containing s at 3.45 for $\left.\mathrm{OCH}_{3}, \mathrm{C}(4) H, \mathrm{C}(10) H\right], 4.64[1 \mathrm{H}, \mathrm{dd}, J 7,3, \mathrm{C}(11) H], 7.88(1 \mathrm{H}, \mathrm{br} \mathrm{s}, \mathrm{N} H) ;\left[{ }^{1} \mathrm{H}\right.$ COSY NMR indicates spin coupling between the signals for $\mathrm{C}(5) H$ and $\mathrm{C}(9) H, \mathrm{C}(11) H$ and 3.38-3.54 $(5 \mathrm{H}, \mathrm{m})$ and between $\mathrm{C}(3 \mathrm{~b}) \mathrm{H}$ and 3.38-3.54 $(5 \mathrm{H}, \mathrm{m})$ ]; [ $\mathrm{In}$ a $\mathrm{CDCl}_{3} / \mathrm{CD}_{3} \mathrm{COCD}_{3}$ mixed solvent the ${ }^{1} \mathrm{H}$ NMR signals for $\mathrm{C}(3 \mathrm{~b}) \mathrm{H}$ and $\mathrm{C}(3 \mathrm{a}) \mathrm{CH}_{3}$ are seen at 1.25 and 1.22 respectively, other signals are found to be at the same chemical shift as described above. A mixed solvent is necessary to dissolve sufficient 25 to obtain ${ }^{13} \mathrm{C}$ NMR spectra]; $\delta_{\mathrm{C}}(67.8 \mathrm{MHz}$; $\left.\mathrm{CDCl}_{3} / \mathrm{CD}_{3} \mathrm{COCD}_{3}\right) 8.7(\mathrm{Me}), 24.9\left(\mathrm{CH}_{2}\right), 29.8(\mathrm{CH}), 33.4\left(\mathrm{CH}_{2}\right), 37.2(\mathrm{CH}), 38.1(\mathrm{CH}), 40.0$ $(\mathrm{C}), 42.0(\mathrm{C}), 46.4(\mathrm{CH}), 46.6(\mathrm{CH}), 55.0(\mathrm{Me}), 92.3(\mathrm{CH}), 156.7(\mathrm{C}), 177.4(\mathrm{C}), 178.6(\mathrm{C})$, 214.1 (C); $m / z$ (EI) 287 (M+, 20\%), 216 (12), 190 (7), 173 (10), 160 (17), 134 (36), 115 (23), 91 (100). 
Adduct 26. (a) Reaction of purified 3,8a-dihydro-6-methoxy-8a-methylazulen-1(2H)-one 14 with $N$-phenylmaleimide.

This was prepared following the procedure described for 20, from 3,8a-dihydro-6-methoxy-8amethylazulen-1(2H)-one 14 (113 mg, $\left.5.95 \times 10^{-4} \mathrm{~mol}\right)$ and $N$-phenylmaleimide (104 mg, $5.98 \mathrm{x}$ $\left.10^{-4} \mathrm{~mol}\right)$ in ethyl acetate $(5 \mathrm{~mL})$. Recrystallization from ethanol-dichloromethane gave the adduct $26(136 \mathrm{mg}, 63 \%)$ as a colorless solid, $\mathrm{mp} 273-276{ }^{\circ} \mathrm{C}$; found $\mathrm{C}, 72.21 ; \mathrm{H}, 5.84 ; \mathrm{N}, 3.66$. $\mathrm{C}_{22} \mathrm{H}_{21} \mathrm{NO}_{4}$ requires $\left.\mathrm{C}, 72.71 ; \mathrm{H}, 5.82 ; \mathrm{N}, 3.85 \%\right) ; v_{\max }(\mathrm{KBr}) 1713,1649 \mathrm{~cm}^{-1} ; \delta_{\mathrm{H}}(270 \mathrm{MHz}$; $\left.\mathrm{CDCl}_{3}\right)$ 1.12-1.29 [4H, m, containing $3 \mathrm{H}$ s at 1.17 for $\left.\mathrm{C}(3 \mathrm{a}) \mathrm{CH}_{3}, \mathrm{C}(3 \mathrm{~b}) \mathrm{H}\right], 2.05-2.37$ [4H, m, $\left.\mathrm{C}(1) \mathrm{H}_{2}, \mathrm{C}(2) \mathrm{H}_{2}\right], 3.21$ [1H, dd, $J$ 7, 3, one of $\left.\mathrm{C}(5) H, \mathrm{C}(9) H\right], 3.37-3.54$ [5H, m, containing s at 3.45 for $\mathrm{OCH}_{3}, \mathrm{C}(4) H$ and one of $\left.\mathrm{C}(5) H, \mathrm{C}(9) H\right], 3.57$ [1H, dd, $J$ 7, 3, C(10)H], $4.68[1 \mathrm{H}$, dd, $J$ 7, 2, $\mathrm{C}(11) H], 7.11-7.22(2 \mathrm{H}, \mathrm{m}, \mathrm{Ar} H), 7.33-7.52(3 \mathrm{H}, \mathrm{m}, \mathrm{Ar} H) ; \delta_{\mathrm{C}}\left(67.8 \mathrm{MHz} ; \mathrm{CDCl}_{3}\right) 8.7$ (Me), $24.8\left(\mathrm{CH}_{2}\right), 29.8(\mathrm{CH}), 33.4\left(\mathrm{CH}_{2}\right), 37.7(\mathrm{CH}), 38.5(\mathrm{CH}), 39.7(\mathrm{C}), 42.1(\mathrm{C}), 45.2(\mathrm{CH})$, $45.3(\mathrm{CH}), 54.9(\mathrm{Me}), 92.4(\mathrm{CH}), 126.6(\mathrm{CH}), 128.5(\mathrm{CH}), 129.0(\mathrm{CH}), 131.9(\mathrm{C}), 156.7(\mathrm{C})$, $175.5(\mathrm{C}), 177.0(\mathrm{C}), 213.6(\mathrm{C}) ; \mathrm{m} / z$ (EI) found 363.1474. $\mathrm{C}_{22} \mathrm{H}_{21} \mathrm{NO}_{4}$ requires $\mathrm{M}^{+} 363.1471$ (M+, 24\%), 294 (26), 266 (15), 190 (10), 173 (22), 147 (20), 91 (100).

(b) One pot preparation of adduct 26 from $N$-phenylmaleimide and 2-diazo-5-(4'methoxyphenyl)pentan-3-one 8.

This was prepared following the procedure described for 18, from 2-diazo-5-(4'methoxyphenyl)pentan-3-one $8\left(150 \mathrm{mg}, 6.88 \times 10^{-4} \mathrm{~mol}\right)$ in dichloromethane $(100 \mathrm{~mL})$ and rhodium(II) acetate $(0.5 \mathrm{mg})$ in dichloromethane $(100 \mathrm{~mL})$ to yield the crude azulenone 14. $\mathrm{N}$ Phenylmaleimide $\left(121 \mathrm{mg}, 6.95 \times 10^{-4} \mathrm{~mol}\right)$ was added to the crude azulenone in ethyl acetate $(5 \mathrm{~mL})$ and the procedure described for 18 followed. Adduct 26 (128 mg, 51\%) was isolated as a white solid which was found to have spectral characteristics the same as those described above.

Adduct 27. One pot preparation of adduct 27 from maleic anhydride and 2-diazo-5-(4methoxyphenyl)hexan-3-one 9.

This was prepared following the procedure described for 18, from 2-diazo-5-(4methoxyphenyl)hexan-3-one $9\left(113 \mathrm{mg}, 4.86 \times 10^{-4} \mathrm{~mol}\right)$ in dichloromethane $(100 \mathrm{~mL})$ and rhodium acetate $(0.5 \mathrm{mg})$ in dichloromethane $(100 \mathrm{~mL})$ to give the crude azulenone 15 . Maleic anhydride (48 mg, $\left.4.90 \times 10^{-4} \mathrm{~mol}\right)$ was added to the crude azulenone in ethyl acetate $(5 \mathrm{~mL})$ and the procedure described for $\mathbf{1 8}$ followed. Recrystallization from ethanol-dichloromethane gave the adduct 27 (37 mg, 25\%) as a colorless solid, mp 205-206 ${ }^{\circ} \mathrm{C}$; found $\mathrm{C}, 67.89 ; \mathrm{H}, 6.13 \%$ $\mathrm{C}_{17} \mathrm{H}_{18} \mathrm{O}_{5}$ requires $\mathrm{C}, 67.54 ; \mathrm{H}, 6.00 \%$; $v_{\max }(\mathrm{KBr}) 1778,1718,1648 \mathrm{~cm}^{-1} ; \delta_{\mathrm{H}}\left(270 \mathrm{MHz} ; \mathrm{CDCl}_{3}\right)$ $1.18\left[3 \mathrm{H}, \mathrm{d}, J 7, \mathrm{C}(1) \mathrm{CH}_{3}\right], 1.23\left[3 \mathrm{H}, \mathrm{s}, \mathrm{C}(3 \mathrm{a}) \mathrm{CH}_{3}\right], 1.29[1 \mathrm{H}, \mathrm{d}, J 4, \mathrm{C}(3 \mathrm{~b}) H], 1.81-1.97$ [1H, A of $\mathrm{ABX}$, appears as d, $J 16$, one of $\left.\mathrm{C}(2) H_{2}\right], 2.26-2.47$ [2H, m, $\mathrm{C}(3) H$, one of $\left.\mathrm{C}(2) H_{3}\right], 3.35-3.52$ $\left\{6 \mathrm{H}, \mathrm{m}\right.$, containing [1H, dd, $J 9,4$ at 3.38 for one of $\mathrm{C}(5) \mathrm{H}, \mathrm{C}(9) \mathrm{H}$ and $3 \mathrm{H}$ s at 3.50 for $\left.\mathrm{OCH}_{3}\right]$, $\mathrm{C}(4) H$ and other of $\mathrm{C}(5) H, \mathrm{C}(9) H\}, 3.75[1 \mathrm{H}, \mathrm{dd}, J 7,3, \mathrm{C}(10) H] ,4.72[1 \mathrm{H}, \mathrm{dd}, J 7,2, \mathrm{C}(11) H]$; $\delta_{\mathrm{C}}\left(67.8 \mathrm{MHz} ; \mathrm{CDCl}_{3}\right) 8.7(\mathrm{Me}), 20.1(\mathrm{Me}), 29.1(\mathrm{CH}), 30.6(\mathrm{CH}), 33.8(\mathrm{CH}), 38.4(\mathrm{CH}), 39.3$ (C), $42.0\left(\mathrm{CH}_{2}\right), 45.4(\mathrm{CH}), 46.1(\mathrm{CH}), 46.3(\mathrm{C}), 55.3(\mathrm{Me}), 92.9(\mathrm{C}), 157.5(\mathrm{C}), 170.4(\mathrm{C}), 171.9$ (C), $212.8(\mathrm{C}) ; \mathrm{m} / \mathrm{z}$ (EI) found 302.1162. $\mathrm{C}_{17} \mathrm{H}_{18} \mathrm{O}_{5}$ requires $\mathrm{M}^{+}$302.1154; 302 (5\%), 294 (2), 274 (2), 229 7), 204 (1), 188 (15), 134 (45), 108 (20), 91(100). 
Adduct 28. Reaction of purified trans-(3R*,8a $\left.R^{*}\right)-3,8 \mathrm{a}$-dihydro-6-methoxy-3,8a-

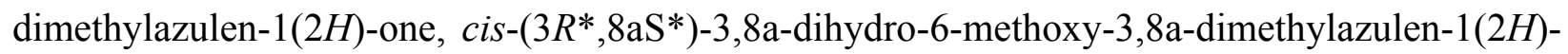
one 15 with maleimide.

This was prepared following the procedure described for 20 , from trans- $\left(3 R^{*}, 8 \mathrm{a} R^{*}\right)-3,8 \mathrm{a}-$ dihydro-6-methoxy-3,8a-dimethylazulen-1(2H)-one, $\quad c i s-\left(3 R^{*}, 8 \mathrm{aS} *\right)-3,8 \mathrm{a}$-dihydro-6-methoxy3,8a-dimethylazulen-1(2H)-one 15 (trans:cis, 80:20) (97 mg, $4.75 \times 10^{-4} \mathrm{~mol}$ ) and maleimide (46 mg, $\left.4.74 \times 10^{-4} \mathrm{~mol}\right)$ in ethyl acetate $(5 \mathrm{~mL})$. Recrystallization from hot ethanol gave the adduct 28 (113 mg, 79\%) as a colorless solid, mp 174-175 ${ }^{\circ} \mathrm{C}$. There was an indication of a minor diastereomer in the ${ }^{1} \mathrm{H}$ and ${ }^{13} \mathrm{C} \mathrm{NMR} \sim 7 \%$; found $\mathrm{C}, 67.92 ; \mathrm{H}, 6.58 ; \mathrm{N}, 5.13 \% \mathrm{C}_{17} \mathrm{H}_{19} \mathrm{NO}_{4}$ requires $\mathrm{C}, 67.78 ; \mathrm{H}, 6.36 ; \mathrm{N}, 4.65 \% ; v_{\max }(\mathrm{KBr}) 1715,1651 \mathrm{~cm}^{-1} ; \delta_{\mathrm{H}}\left(270 \mathrm{MHz} ; \mathrm{CDCl}_{3}\right) 1.15$ $\left[1 \mathrm{H}, \mathrm{d}, J 6, \mathrm{C}(3) \mathrm{CH}_{3}\right], 1.22$ [3H, s, C(3a)CH3 $\mathrm{CH}_{3} 1.29$ [1H, d, $\left.J 4, \mathrm{C}(3 \mathrm{~b}) H\right], 1.77-1.93$ [1 $\mathrm{H}$, one of $\left.\mathrm{C}(2) H_{2}\right], 2.28-2.50$ [2H, m, C(3)H, one of $\left.\mathrm{C}(2) H_{2}\right], 3.13$ [1H, dd, $J 8,4$, one of $\left.\mathrm{C}(5) H, \mathrm{C}(9) H\right]$, $3.26[1 \mathrm{H}, \mathrm{dd}, J 8,3$, one of $\mathrm{C}(5) H, \mathrm{C}(9) H], 3.33-3.42[1 \mathrm{H}, \mathrm{m}, \mathrm{C}(4) H], 3.45\left(3 \mathrm{H}, \mathrm{s}, \mathrm{OCH}_{3}\right), 3.66$ $[1 \mathrm{H}, \mathrm{dd}, J 7,3, \mathrm{C}(10) H], 4.65[1 \mathrm{H}, \mathrm{dd}, J 7,2, \mathrm{C}(11) H], 8.87\left(1 \mathrm{H}\right.$, br s, NH); $\delta_{\mathrm{C}}(67.8 \mathrm{MHz}$; $\left.\mathrm{CDCl}_{3}\right) 8.7(\mathrm{Me}), 19.9(\mathrm{Me}), 30.0(\mathrm{CH}), 30.2(\mathrm{CH}), 33.1(\mathrm{CH}), 38.1(\mathrm{CH}), 39.3(\mathrm{C}), 42.0\left(\mathrm{CH}_{2}\right)$, $45.1(\mathrm{CH}), 46.5(\mathrm{CH}), 46.7(\mathrm{C}), 54.8(\mathrm{Me}), 92.3(\mathrm{CH}), 156.7(\mathrm{C}), 177.0(\mathrm{C}), 178.2(\mathrm{C}), 213.5$ (C); $m / z(\mathrm{EI})$ found 301.1316. $\mathrm{C}_{17} \mathrm{H}_{19} \mathrm{NO}_{4}$ requires $\mathrm{M}+301.1314,301$ (100\%), 286 (10), 230 (10), 204 (18), 189 (27), 162 (32), 135 (50), 108 (34), 91 (64).

The minor diastereomer $(\sim 7 \%)$ could be detected in the ${ }^{1} \mathrm{H}$ NMR at $\delta_{\mathrm{H}} 4.73[1 \mathrm{H}, \mathrm{dd}, J 7,2$, $\mathrm{C}(11) H], 3.43\left(\mathrm{~s}, \mathrm{OCH}_{3}\right)$ and in the ${ }^{13} \mathrm{C} \mathrm{NMR}$ at $\delta_{\mathrm{C}} 9.2(\mathrm{Me}), 17.4(\mathrm{Me}), 27.8(\mathrm{CH}), 36.0,38.3$, $41.3(\mathrm{CH}), 45.1(\mathrm{CH}), 47.7(\mathrm{CH}), 93.8(\mathrm{CH}), 156.3(\mathrm{C})$. Maleimide could be detected at $\delta_{\mathrm{C}} 67$ and 135.

Adduct 29. Reaction of purified trans-(3R*,8a $\left.R^{*}\right)-3,8 \mathrm{a}$-dihydro-6-methoxy-3,8adimethylazulen-1(2H)-one, cis-(3R*,8aS*)-3,8a-dihydro-6-methoxy-3,8a-dimethylazulen-1(2H)one 15 with $N$-phenylmaleimide.

This was prepared following the procedure described for 20, from trans- $\left(3 R^{*}, 8 \mathrm{a} R^{*}\right)-3,8 \mathrm{a}-$ dihydro-6-methoxy-3,8a-dimethylazulen-1(2H)-one, cis-(3R*,8aS*)-3,8a-dihydro-6-methoxy3,8a-dimethylazulen-1(2H)-one 15 (trans:cis, 82:18) (121 mg, $\left.5.93 \times 10^{-4} \mathrm{~mol}\right)$ and $\mathrm{N}$ phenylmaleimide $\left(103 \mathrm{mg}, 5.93 \times 10^{-4} \mathrm{~mol}\right)$ in ethyl acetate $(5 \mathrm{~mL})$. Recrystallization from ethanol-dichloromethane gave the adduct $29(101 \mathrm{mg}, 45 \%)$ as a colorless solid, mp 189$191{ }^{\circ} \mathrm{C}$; found $\mathrm{C}, 73.55 ; \mathrm{H}, 5.88 ; \mathrm{N}, 3.61 \% \mathrm{C}_{23} \mathrm{H}_{23} \mathrm{NO}_{4}$ requires $\mathrm{C}, 73.19 ; \mathrm{H}, 6.14 ; \mathrm{N}, 3.71 \%$; $v_{\max }(\mathrm{KBr}) 1710,1649 \mathrm{~cm}^{-1} ; \delta_{\mathrm{H}}\left(270 \mathrm{MHz} ; \mathrm{CDCl}_{3}\right) 1.18\left[3 \mathrm{H}, \mathrm{d}, J 7, \mathrm{C}(1) \mathrm{CH}_{3}\right], 1.23[3 \mathrm{H}, \mathrm{s}$, $\left.\mathrm{C}(3 \mathrm{a}) \mathrm{CH}_{3}\right], 1.35[1 \mathrm{H}, \mathrm{d}, J 4, \mathrm{C}(3 \mathrm{~b}) H], 1.77-1.93\left[1 \mathrm{H}, \mathrm{m}\right.$, one of $\left.\mathrm{C}(2) H_{2}\right], 2.33-2.49$ [2H, m, $\mathrm{C}(3) H$, one of $\left.\mathrm{C}(2) H_{2}\right], 3.22[1 \mathrm{H}, \mathrm{dd}, J 8,4$, one of $\mathrm{C}(5) H, \mathrm{C}(9) H], 3.37[1 \mathrm{H}, \mathrm{dd}, J 8$, 4, one of $\mathrm{C}(5) H, \mathrm{C}(9) H], 3.42-3.53\left[4 \mathrm{H}, \mathrm{m}\right.$, containing s at 3.47 for $\left.\mathrm{OCH}_{3}, \mathrm{C}(4) H\right], 3.77[1 \mathrm{H}, \mathrm{dd}, J$ 8, 3, $\mathrm{C}(10) H], 4.68[1 \mathrm{H}, \mathrm{dd}, J 7,3, \mathrm{C}(11) H], 7.09-7.23(2 \mathrm{H}, \mathrm{m}, \mathrm{Ar} H), 7.33-7.54(3 \mathrm{H}, \mathrm{m}, \mathrm{Ar} H) ; \delta_{\mathrm{C}}$ $\left(67.8 \mathrm{MHz} ; \mathrm{CDC}_{3}\right) 8.9(\mathrm{Me}), 20.1(\mathrm{Me}), 30.1(\mathrm{CH}), 31.4(\mathrm{CH}), 33.8(\mathrm{CH}), 38.6(\mathrm{CH}), 39.2(\mathrm{C})$, $42.1\left(\mathrm{CH}_{2}\right), 44.6(\mathrm{CH}), 45.2(\mathrm{CH}), 46.9(\mathrm{C}), 55.0(\mathrm{Me}), 92.5(\mathrm{CH}), 126.3(\mathrm{CH}), 128.6(\mathrm{CH})$, $129.2(\mathrm{CH}), 131.8(\mathrm{C}), 156.9(\mathrm{C}), 175.7(\mathrm{C}), 177.0(\mathrm{C}), 213.6(\mathrm{C}) ; \mathrm{m} / \mathrm{z}(\mathrm{EI})$ found 377.1626. 
$\mathrm{C}_{23} \mathrm{H}_{23} \mathrm{NO}_{4}$ requires $\mathrm{M}^{+}$377.1627; 377 (100\%), 362 (7), 255 (18), 230 (15), 204 (20), 189 (30), 162 (35), 135 (80), 108 (61), 91 (33).

An X-ray crystal structure was obtained of a single crystal of the adduct 29 obtained by recrystallization from ethanol/ dichloromethane. We have reported the details of this X-ray crystal structure previously. 6,9

(b) One pot preparation of adduct 29 from $N$-phenylmaleimide and 2-diazo-5-(4'methoxyphenyl)hexan-3-one 9.

This was prepared following the procedure described for 18, from 2-diazo-5-(4'methoxyphenyl)hexan-3-one $9\left(150 \mathrm{mg}, 6.47 \times 10^{-4} \mathrm{~mol}\right)$ in dichloromethane $(100 \mathrm{~mL})$ and rhodium acetate $(0.5 \mathrm{mg})$ in dichloromethane $(100 \mathrm{~mL})$ to give the crude azulenone 15 . $N$ Phenylmaleimide $\left(113 \mathrm{mg}, 6.49 \times 10^{-4} \mathrm{~mol}\right)$ was added to the crude azulenone in ethyl acetate $(5 \mathrm{~mL})$ and the procedure described for 18 followed. The adduct 29 (120 mg, 49\%) was isolated as a white solid. The spectral characteristics of the product were found to be the same as those described above except there was an indication of a signal tentatively assigned as a minor diastereomer in the ${ }^{1} \mathrm{H}$ NMR ( $\mathrm{m}$ at $4.78,<2 \%$ ). There was no indication of the minor diastereomer in the ${ }^{13} \mathrm{C}$ NMR.

Adduct 30. (a) Reaction of purified trans-(3R*,8aS*)-3,8a-dihydro-6-methoxy-3-isopropyl-8amethylazulen-1(2H)-one, cis-(3R*,8a $\left.R^{*}\right)$-3,8a-dihydro-6-methoxy-3-isopropyl-8a-methylazulen$1(2 H)$-one 16 with maleic anhydride.

This was prepared following the procedure described for 20, from trans- $\left(3 R^{*}, 8 \mathrm{aS} *\right)-3,8 \mathrm{a}-$ dihydro-6-methoxy-3-isopropyl-8a-methylazulen-1(2H)-one, $\quad$ cis-(3R*,8a $\left.R^{*}\right)-3,8 \mathrm{a}$-dihydro-6methoxy-3-isopropyl-8a-methylazulen-1(2H)-one 16 (trans:cis, 90:10) (66 mg, 2.85 x 10-4 mol) and maleic anhydride $\left(28 \mathrm{mg}, 2.86 \times 10^{-4} \mathrm{~mol}\right)$ in ethyl acetate $(5 \mathrm{~mL})$. Recrystallization from ethanol-dichloromethane gave the adduct 30 (42 mg, 45\%) as a colorless solid, mp 208-210 $C$; found $\mathrm{C}$, 69.24; $\mathrm{H}, 6.70 . \mathrm{C}_{19} \mathrm{H}_{22} \mathrm{O}_{5}$ requires $\mathrm{C}, 69.07 ; \mathrm{H}, 6.71 \% ; v_{\max }(\mathrm{KBr}) 1778,1723,1651 \mathrm{~cm}^{-1} ; \delta_{\mathrm{H}}(270$ $\left.\mathrm{MHz} ; \mathrm{CDCl}_{3}\right) 0.67\left(3 \mathrm{H}, \mathrm{d}, J\right.$, one of $\mathrm{CH}_{3}$ of $\left.\operatorname{Pr}^{\mathrm{i}}\right), 0.95\left(3 \mathrm{H}, \mathrm{d}, J\right.$, one of $\mathrm{CH}_{3}$ of $\left.\operatorname{Pr}^{\mathrm{i}}\right), 1.14[1 \mathrm{H}$, $\mathrm{d}, J 4, \mathrm{C}(3 \mathrm{~b}) H], 1.21\left[3 \mathrm{H}, \mathrm{s}, \mathrm{C}(3 \mathrm{a}) \mathrm{CH}_{3}\right], 2.03-2.13,2.18-2.37$ [2 x $2 \mathrm{H}, 2 \mathrm{x} \mathrm{m}, \mathrm{C}(2) H 2, \mathrm{C}(3) H$, $\mathrm{CH}$ of $\mathrm{Pr}^{\mathrm{i}}$ ], 3.34-3.59 $\{6 \mathrm{H}, \mathrm{m}$, containing [1H, dd $J 8,4$ at 3.38 for one of $\mathrm{C}(5) H, \mathrm{C}(9) H$ and $3 \mathrm{H} \mathrm{s}$ at 3.49 for $\left.\mathrm{OCH}_{3}\right], \mathrm{C}(4) H$, other of C (5)H, C(9)H\}, $3.74[1 \mathrm{H}, \mathrm{dd}, J 7,3, \mathrm{C}(10) H], 4.71[1 \mathrm{H}, \mathrm{dd}, J$ 7, 3, C(11)H],; $\delta_{\mathrm{C}}\left(67.8 \mathrm{MHz} ; \mathrm{CDCl}_{3}\right) 8.5(\mathrm{Me}), 14.7(\mathrm{Me}), 20.6(\mathrm{Me}), 28.3(\mathrm{CH}), 29.4(\mathrm{CH})$, $32.1(\mathrm{CH}), 34.1\left(\mathrm{CH}_{2}\right), 38.3(\mathrm{CH}), 40.1(\mathrm{C}), 40.5(\mathrm{CH}), 43.6(\mathrm{C}), 45.3(\mathrm{CH}), 45.9(\mathrm{CH}), 55.2$ (Me), $92.6(\mathrm{CH}), 157.6(\mathrm{C}), 170.4(\mathrm{C}), 171.9(\mathrm{C}), 213.5(\mathrm{C}) ; \mathrm{m} / z(\mathrm{EI})$ found $330.1469 . \mathrm{C}_{19} \mathrm{H}_{22} \mathrm{O}_{5}$ requires $\mathrm{M}^{+} 330.1467 ; 330$ (27\%), 232 (7), 221 (28), 150 (50), 108 (67), 44 (100).

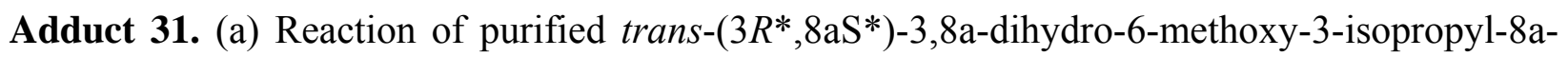
methylazulen-1(2H)-one, cis-(3R*,8a $\left.R^{*}\right)$-3,8a-dihydro-6-methoxy-3-isopropyl-8a-methylazulen1(2H)-one 16 with maleimide.

This was prepared following the procedure described for 20, from trans- $\left(3 R^{*}, 8 \mathrm{aS} *\right)-3,8 \mathrm{a}-$ dihydro-6-methoxy-3-isopropyl-8a-methylazulen-1(2H)-one, $\quad$ cis-(3R*,8a $\left.R^{*}\right)-3,8 \mathrm{a}$-dihydro-6methoxy-3-isopropyl-8a-methylazulen-1(2H)-one 16 (trans:cis, 80:20) (80 mg, 3.45 x 10 $0^{-4} \mathrm{~mol}$ ) and maleimide $\left(33 \mathrm{mg}, 3.45 \times 10^{-4} \mathrm{~mol}\right)$ in ethyl acetate $(5 \mathrm{~mL})$. Recrystallization from ethanol- 
dichloromethane gave the adduct 31 (47 mg, 41\%) as a colorless solid, mp 232-234 ${ }^{\circ} \mathrm{C}$; found C, 69.55; H, 6.85; N, 4.12\% $\mathrm{C}_{19} \mathrm{H}_{23} \mathrm{NO}_{4}$ requires C, 69.28; H, 7.04; N, 4.25\%; $v_{\max }\left(\mathrm{KBr}_{)} 1716\right.$, $1651 \mathrm{~cm}^{-1} ; \delta_{\mathrm{H}}\left(270 \mathrm{MHz} ; \mathrm{CDCl}_{3}\right) 0.66\left(3 \mathrm{H}, \mathrm{d}, J 7\right.$, one of $\mathrm{CH}_{3}$ of $\left.\operatorname{Pr}^{\mathrm{i}}\right), 0.93(3 \mathrm{H}, \mathrm{d}, J 7$, one of $\mathrm{CH}_{3}$ of $\left.\operatorname{Pr}^{\mathrm{i}}\right), 1.13$ [1H, d, J 4, C(3b)H], 1.21 [3H, s, C(3a)CH3], 2.03-2.12, 2.19-2.34 [2 x 2H, 2 x $\mathrm{m}, \mathrm{C}(2) \mathrm{H}_{2}, \mathrm{C}(3) H, \mathrm{CH}$ of $\left.\mathrm{Pr}^{\mathrm{i}}\right], 3.12,3.26[2 \times 1 \mathrm{H}, 2 \mathrm{x}$ dd, $J$ 8, 4, C(5)H, C(9)H], 3.33-3.58 [4H, $\mathrm{m}$, containing s at 3.45 for $\left.\mathrm{OCH}_{3}, \mathrm{C}(4) H\right], 3.65[1 \mathrm{H}, \mathrm{dd}, J 8,4, \mathrm{C}(10) H], 4.63[1 \mathrm{H}, \mathrm{dd}, J 8,4$, $\mathrm{C}(11) H], 8.01(1 \mathrm{H}$, br s, $\mathrm{NH}) ; \delta_{\mathrm{C}}\left(67.8 \mathrm{MHz} ; \mathrm{CDCl}_{3}\right) 8.7(\mathrm{Me}), 14.7(\mathrm{Me}), 20.6(\mathrm{Me}), 28.2(\mathrm{CH})$, $30.0(\mathrm{CH}), 32.9(\mathrm{CH}), 34.2\left(\mathrm{CH}_{2}\right), 38.0(\mathrm{CH}), 40.0(\mathrm{C}), 40.6(\mathrm{CH}), 44.0(\mathrm{C}), 45.8(\mathrm{CH}), 46.4$ $(\mathrm{CH}), 55.0(\mathrm{Me}), 92.1(\mathrm{CH}), 157.0(\mathrm{C}), 176.5(\mathrm{C}), 177.9(\mathrm{C}), 214.1(\mathrm{C}) ; \mathrm{m} / z(\mathrm{EI})$ found 329.1623. $\mathrm{C}_{19} \mathrm{H}_{23} \mathrm{NO}_{4}$ requires $\mathrm{M}^{+}$329.1627; 329 (20\%), 286 (2), 232 (4), 215 (25), 179 (18), 161 (22), 134 (20), 108 (38), 91 (40), 43 (100).

Adduct 32. (a) Reaction of purified trans-(3R*,8aS*)-3,8a-dihydro-6-methoxy-3-isopropyl-8amethylazulen-1(2H)-one, cis-(3R*,8a $\left.R^{*}\right)$-3,8a-dihydro-6-methoxy-3-isopropyl-8a-methylazulen$1(2 H)$-one 16 with $N$-phenylmaleimide.

This was prepared following the procedure described for 20, from trans- $\left(3 R^{*}, 8 \mathrm{aS} *\right)-3,8 \mathrm{a}-$ dihydro-6-methoxy-3-isopropyl-8a-methylazulen-1(2H)-one, $\quad$ cis-(3R*,8a $\left.R^{*}\right)-3,8 \mathrm{a}-\mathrm{dihydro}-6$ methoxy-3-isopropyl-8a-methylazulen-1(2H)-one 16 (trans:cis, 80:20) (69 mg, 2.97 x 10-4 mol) and $N$-phenylmaleimide $\left(52 \mathrm{mg}, 2.99 \times 10^{-4} \mathrm{~mol}\right)$ in ethyl acetate $(5 \mathrm{~mL})$. Recrystallization from ethanol-dichloromethane gave the adduct $32(38 \mathrm{mg}, 32 \%)$ as a colorless solid, $\mathrm{mp} 229-230{ }^{\circ} \mathrm{C}$; found $\mathrm{C}$, 73.97; $\mathrm{H}, 6.98 ; \mathrm{N}, 3.60 \% \mathrm{C}_{25} \mathrm{H}_{27} \mathrm{NO}_{4}$ requires $\mathrm{C}, 74.06 ; \mathrm{H}, 6.70 ; \mathrm{N}, 3.60 \% ; v_{\max }(\mathrm{KBr})$ $1713,1651 \mathrm{~cm}^{-1} ; \delta_{\mathrm{H}}\left(270 \mathrm{MHz} ; \mathrm{CDCl}_{3}\right) 0.68\left(3 \mathrm{H}, \mathrm{d}, J 7\right.$, one of $\mathrm{CH}_{3}$ of $\left.\mathrm{Pr}^{\mathrm{i}}\right), 0.94(3 \mathrm{H}, \mathrm{d}, J 7$, one of $\mathrm{CH}_{3}$ of $\left.\mathrm{Pr}^{\mathrm{i}}\right), 1.18$ [1H, d, J 4, C(3b)H], 1.23 [3H, s, C(3a)CH $\mathrm{CH}_{3}$, 2.04-2.22, 2.25-2.42 [2 x $2 \mathrm{H}, 2 \times \mathrm{m}, \mathrm{C}(2) H_{2}, \mathrm{C}(3) H, \mathrm{CH}$ of $\left.\operatorname{Pr}^{\mathrm{i}}\right], 3.21,3.36[2 \times 1 \mathrm{H}, 2 \times \mathrm{dd}, J 8,4, \mathrm{C}(5) H, \mathrm{C}(9) H], 3.42-$ $3.57\left[4 \mathrm{H}, \mathrm{m}\right.$, containing s at 3.46 for $\left.\mathrm{OCH}_{3}, \mathrm{C}(4) H\right], 3.75[1 \mathrm{H}, \mathrm{dd}, J 7,3, \mathrm{C}(10) H], 4.68[1 \mathrm{H}$, dd, $J$ 7, 4, C(11)H], 7.10-7.22 (2H, m, ArH), 7.33-7.54 (3H, m, $\mathrm{ArH}) ; \delta_{\mathrm{C}}\left(67.8 \mathrm{MHz} ; \mathrm{CDCl}_{3}\right) 8.7$ $(\mathrm{Me}), 14.7(\mathrm{Me}), 20.6(\mathrm{Me}), 28.2(\mathrm{CH}), 30.1(\mathrm{CH}), 33.5(\mathrm{CH}), 34.2\left(\mathrm{CH}_{2}\right), 38.5(\mathrm{CH}), 39.9(\mathrm{C})$, $40.7(\mathrm{CH}), 44.1(\mathrm{C}), 44.5(\mathrm{CH}), 45.0(\mathrm{CH}), 54.9(\mathrm{Me}), 92.3(\mathrm{CH}), 126.2(\mathrm{CH}), 128.5(\mathrm{CH}), 129.0$ (CH), $131.9(\mathrm{C}), 157.1(\mathrm{C}), 175.4(\mathrm{C}), 176.9(\mathrm{C}), 213.8(\mathrm{C}) ; \mathrm{m} / z$ (EI) found 405.1941. $\mathrm{C}_{25} \mathrm{H}_{27} \mathrm{NO}_{4}$ requires $\mathrm{M}^{+}$405.1940; 405 (1\%), 362 (1), 327 (1), 239 (3), 206 (2), 173 (100), 129 (30), 103 (30).

Adduct 37. (a) One pot preparation of adduct 37 from maleic anhydride and 2-diazo-5-(2'methoxyphenyl)pentan-3-one 33.

This was prepared following the procedure described for 18, from 2-diazo-5-(2'methoxyphenyl)pentan-3-one $33\left(221 \mathrm{mg}, 1.01 \times 10^{-3} \mathrm{~mol}\right)$ in dichloromethane $(150 \mathrm{~mL})$ and rhodium perfluorobutyrate $(0.5 \mathrm{mg})$ in dichloromethane $(100 \mathrm{~mL})$ to give the crude azulenone 35 (as a mixture of the 4-methoxy and 8-methoxy isomers 9:1). Maleic anhydride (99 $\mathrm{mg}, 1.02 \mathrm{x}$ $\left.10^{-3} \mathrm{~mol}\right)$ was added to the crude azulenone in ethyl acetate $(7 \mathrm{~mL})$ and the procedure described for 18 followed. Recrystallization from hexane-dichloromethane gave the adduct 37 (174 mg, $60 \%$ ) as a colorless solid, mp $192-193{ }^{\circ} \mathrm{C}$; found $\mathrm{C}$, 66.35; $\mathrm{H}, 5.64 \% \mathrm{C}_{16} \mathrm{H}_{16} \mathrm{O}_{5}$ requires $\mathrm{C}$, 66.66; $\mathrm{H}, 5.59 \% ; v_{\max }(\mathrm{KBr}) 1778,1713 \mathrm{~cm}^{-1} ; \delta_{\mathrm{H}}\left(270 \mathrm{MHz} ; \mathrm{CDCl}_{3}\right) 1.29\left[3 \mathrm{H}, \mathrm{s}, \mathrm{C}(3 \mathrm{a}) \mathrm{CH}_{3}\right], 1.40[1 \mathrm{H}$, 
d, $J 4, \mathrm{C}(3 \mathrm{~b}) H], 1.88-2.04\left[1 \mathrm{H}, \mathrm{m}\right.$, one of $\mathrm{C}(2) \mathrm{H}_{2}$ or one of $\left.\mathrm{C}(1) \mathrm{H}_{2}\right], 2.05-2.40[3 \mathrm{H}, \mathrm{m}$, three of $\left.\mathrm{C}(1) \mathrm{H}_{2}, \mathrm{C}(2) \mathrm{H}_{2}\right], 3.45\left(3 \mathrm{H}, \mathrm{s}, \mathrm{OCH}_{3}\right), 3.51-3.74[3 \mathrm{H}, \mathrm{m}, \mathrm{C}(4) H, \mathrm{C}(5) H, \mathrm{C}(9) H], 6.18$ [1H, dd, appears as t, $J$ 7, C(12)H], $6.39[1 \mathrm{H}, \mathrm{d}, J 9, \mathrm{C}(11) H]$; $\delta_{\mathrm{C}}\left(67.8 \mathrm{MHz} ; \mathrm{CDCl}_{3}\right) 11.9(\mathrm{Me}), 20.9$ $\left(\mathrm{CH}_{2}\right), 31.6(\mathrm{CH}), 32.5\left(\mathrm{CH}_{2}\right), 33.9(\mathrm{CH}), 39.8(\mathrm{C}), 41.1(\mathrm{C}), 47.9(\mathrm{CH}), 48.8(\mathrm{CH}), 53.1(\mathrm{Me})$, $82.0(\mathrm{C}), 130.5(\mathrm{CH}), 132.2(\mathrm{CH}), 168.5(\mathrm{C}), 170.5(\mathrm{C}), 213.0(\mathrm{C}) ; \mathrm{m} / z$ (EI) found 288.1017. $\mathrm{C}_{16} \mathrm{H}_{16} \mathrm{O}_{5}$ requires $\mathrm{M}+288.0998 ; 288$ (5), 260 (5), 222 (17), 190 (100), 162 (88), 91 (88).

Adduct 38. (a) One pot preparation of adduct 38 from maleimide and 2-diazo-5-(2methoxyphenyl)pentan-3-one 33.

This was prepared following the procedure described for 18, from 2-diazo-5-(2methoxyphenyl)pentan-3-one $33\left(195 \mathrm{mg}, 8.94 \times 10^{-4} \mathrm{~mol}\right)$ in dichloromethane $(150 \mathrm{~mL})$ and rhodium acetate $(0.5 \mathrm{mg})$ in dichloromethane $(100 \mathrm{~mL})$ to give the crude azulenone 35 . Maleimide $\left(87 \mathrm{mg}, 8.97 \times 10^{-4} \mathrm{~mol}\right)$ was added to the crude azulenone in ethyl acetate $(7 \mathrm{~mL})$ and the procedure followed. Recrystallization from hexane-dichloromethane gave the adduct 38 $(162 \mathrm{mg}, 63 \%)$ as a colorless solid, $\mathrm{mp} 209-210{ }^{\circ} \mathrm{C}$; found $\mathrm{C}, 66.61 ; \mathrm{H}, 5.93 ; \mathrm{N}, 5.14$. $\mathrm{C}_{16} \mathrm{H}_{17} \mathrm{NO}_{4}$ requires $\mathrm{C}, 66.89 ; \mathrm{H}, 5.96 ; \mathrm{N}, 4.87 \% ; v_{\max }(\mathrm{KBr}) 3173,1775,1725 \mathrm{~cm}^{-1} ; \delta_{\mathrm{H}}(270$ $\left.\mathrm{MHz} ; \mathrm{CDCl}_{3}\right) 1.30\left[3 \mathrm{H}, \mathrm{s}, \mathrm{C}(3 \mathrm{a}) \mathrm{CH}_{3}\right], 1.36[1 \mathrm{H}, \mathrm{d}, J 4, \mathrm{C}(3 \mathrm{~b}) H], 1.92-2,43\left[4 \mathrm{H}, \mathrm{m}, \mathrm{C}(2) \mathrm{H}_{2}\right.$, $\left.\mathrm{C}(3) \mathrm{H}_{2}\right], 3.28$ [1H, dd, $\left.J 8,3, \mathrm{C}(5) H\right], 3.35-3.53$ [4H, m, containing s at 3.45 for $\left.\mathrm{OCH}_{3}, \mathrm{C}(9) H\right]$, 3.655-3.66 [1H, m, C(4)H], 6.09 [1H, dd, appears as t, $J 8,8, \mathrm{C}(12) H], 6.30[1 \mathrm{H}, \mathrm{d}, J 9, \mathrm{C}(11) H]$, $8.23(1 \mathrm{H}$, br s, $\mathrm{N} H) ; \delta_{\mathrm{C}}\left(67.8 \mathrm{MHz} ; \mathrm{CDCl}_{3}\right) 12.1(\mathrm{Me}), 21.2\left(\mathrm{CH}_{2}\right), 32.1,32.7,38.8(2 \times \mathrm{CH}$, $\left.\mathrm{CH}_{2}\right), 40.1(\mathrm{C}), 41.7(\mathrm{C}), 48.1(\mathrm{CH}), 49.6(\mathrm{CH}), 53.1(\mathrm{Me}), 82.5(\mathrm{C}), 129.8(\mathrm{CH}), 131.6(\mathrm{CH})$, $174.9(\mathrm{C}), 176.1(\mathrm{C}), 213.4(\mathrm{C}) ; \mathrm{m} / z$ (EI) found 287.1163. $\mathrm{C}_{16} \mathrm{H}_{17} \mathrm{NO}_{4}$ requires $\mathrm{M}^{+} 287.1158 ; 287$ (4), 272 (4), 259 (4), 244 (3), 190 (47), 175 (48), 162 (43), 147 (58), 131 (44), 117 (67), 91 (100).

Adduct 39. (a) Reaction of purified 3,8a-dihydro-4-methoxy-8a-methylazulen-1(2H)-one, 3,8adihydro-8-methoxy-8a-methylazulen-1(2H)-one 35 with $\mathrm{N}$-phenylmaleimide.

This was prepared following the procedure described for 20, from 3,8a-dihydro-4-methoxy-8amethylazulen-1(2H)-one, 3,8a-dihydro-8-methoxy-8a-methylazulen-1(2H)-one 35 (8-MeO:4$\mathrm{MeO} 63: 37)\left(110 \mathrm{mg}, 5.79 \times 10^{-4} \mathrm{~mol}\right)$ and $N$-phenylmaleimide $\left(101 \mathrm{mg}, 5.80 \times 10^{-4} \mathrm{~mol}\right)$ in ethyl acetate $(5 \mathrm{~mL})$. Recrystallization from ethanol-dichloromethane gave the adduct 39 (128 mg, 61\%) as a colorless solid, mp 194-195 $\mathrm{C}$; found $\mathrm{C}, 73.00 ; \mathrm{H}, 6.10 ; \mathrm{N}, 3.97 . \mathrm{C}_{22} \mathrm{H}_{21} \mathrm{NO}_{4}$ requires $\mathrm{C}, 72.71 ; \mathrm{H}, 5.82 ; \mathrm{N}, 3.85 \%$; $v_{\max }(\mathrm{KBr}) 1710,1502 \mathrm{~cm}^{-1} ; \delta_{\mathrm{H}}\left(270 \mathrm{MHz} ; \mathrm{CDCl}_{3}\right) 1.32$ [3H, s, C(3a)CH $H_{3}$ ], 1.41 [1H, d, $J$ 4, C(3b)H], 1.95-2.42 [4H, m, C(1)H $\left.H_{2}, \mathrm{C}(2) H_{2}\right], 3.35[1 \mathrm{H}, \mathrm{d}, J$ 8, C(9)H], $3.39[1 \mathrm{H}, \mathrm{dd}, J 8,3, \mathrm{C}(5) H], 3.45\left(3 \mathrm{H}, \mathrm{s}, \mathrm{OCH}_{3}\right), 3.64-3.76[1 \mathrm{H}, \mathrm{m}, \mathrm{C}(4) H], 6.14$ $[1 \mathrm{H}, \mathrm{dd}, J 9,7, \mathrm{C}(12) H], 6.51[1 \mathrm{H}, \mathrm{d}, J 8, \mathrm{C}(11) H], 7.15-7.26(2 \mathrm{H}, \mathrm{m}, \operatorname{Ar} H), 7.33-7.52(3 \mathrm{H}, \mathrm{m}$, $\mathrm{Ar} H) ; \delta_{\mathrm{C}}\left(67.8 \mathrm{MHz} ; \mathrm{CDCl}_{3}\right) 12.2(\mathrm{Me}), 21.3\left(\mathrm{CH}_{2}\right), 32.1,32.7,34.3\left(2 \times \mathrm{CH}, \mathrm{CH}_{2}\right), 40.0(\mathrm{C})$, $42.1(\mathrm{C}), 46.9(\mathrm{CH}), 48.2(\mathrm{CH}), 53.1(\mathrm{Me}), 82.8(\mathrm{C}), 126.4(\mathrm{CH}), 128.7(\mathrm{CH}), 129.1(\mathrm{CH}), 129.9$ $(\mathrm{CH}), 131.5(\mathrm{CH}), 131.8(\mathrm{C}), 173.8(\mathrm{C}), 175.5(\mathrm{C}), 213.5(\mathrm{C}) ; \mathrm{m} / z(\mathrm{EI})$ found 363.1486. $\mathrm{C}_{22} \mathrm{H}_{21} \mathrm{NO}_{4}$ requires $\mathrm{M}+363.1471 ; 363$ (48\%), 348 (10), 190 (61), 173 (100\%), 162 (48), 148 (26), 117 (30), 91 (48). 
(b) One pot preparation of adduct 39 from $N$-phenylmaleimide and 2-diazo-5-(2'methoxyphenyl)pentan-3-one 33.

This was prepared following the procedure described for 18, from 2-diazo-5-(2'methoxyphenyl)pentan-3-one $33\left(155 \mathrm{mg}, 7.11 \times 10^{-4} \mathrm{~mol}\right)$ in dichloromethane $(100 \mathrm{~mL})$ and rhodium acetate $(0.5 \mathrm{mg})$ in dichloromethane $(100 \mathrm{~mL})$ to give the crude azulenone $35 . \quad N$ Phenylmaleimide $\left(124 \mathrm{mg}, 7.13 \times 10^{-4} \mathrm{~mol}\right)$ was added to the crude azulenone in ethyl acetate $(5 \mathrm{~mL})$ and the procedure described for 18 followed. Recrystallization from ethanoldichloromethane gave the adduct $39(147 \mathrm{mg}, 57 \%)$ as a colorless solid which had spectral characteristics which are the same as those described above.

\section{Acknowledgements}

The authors would like to thank, Pfizer Pharmaceuticals, Ireland and Enterprise Ireland for their support and Johnson Matthey for a loan of rhodium(II) acetate. The funding of POL's postdoctoral fellowship by the National University of Ireland is also gratefully acknowledged.

\section{References and Notes}

1. For comprehensive reviews see (a) Modern Catalytic Methods for Organic Synthesis with Diazo Compounds, from Cyclopropanes to Ylides Doyle, M. P.; McKervey, M. A.; Ye, T., Eds. Wiley: New York, 1998. (b) Davies, H. M. L.; Beckwith, R. E. J. Chem. Rev. 2003, 103, 2861. (c) Wee, A. G. H. Curr. Org. Synth. 2006, 3, 499. (d) Davies, H. M. L.; Manning, J. R. Nature 2008, 451, 417. (e) Padwa, A.; Weingarten, M. D. Chem. Rev. 1996, 96, 223. (f) Padwa, A.; Hornbuckle, S. F. Chem. Rev. 1991, 91, 263. (f) Doyle M. P.; Forbes, F. C. Chem. Rev. 1998, 98, 911.

2. (a) Padwa, A.; Straub, C. S. J. Org. Chem. 2003, 68, 227. (b) Padwa, A.; Chughtai, M. J.; Boonsombat, J.; Rashatasakhon, R. Tetrahedron 2008, 64, 4758. (c) Padwa, A; Bur, S. C. Tetrahedron 2007, 64, 5341. (d) Muthusamy, S.; Babu, S. A.; Gunanathan; Ganguly, B.; Suresh, E.; Dastidar P. J. Org. Chem. 2002, 67, 8019.

3. (a) Maguire, A. R.; Buckley, N. R.; O'Leary, P.; Ferguson, G. J. Chem. Soc., Chem. Commun. 1996, 2595. (b) Maguire, A. R.; Buckley, N. R.; O'Leary, P.; Ferguson, G. J. Chem. Soc., Perkin Trans. 1 1998, 4077.

4. (a) Modern Catalytic Methods for Organic Synthesis with Diazo Compounds, Doyle, M. P.; McKervey, M. A.; Ye, T., Eds. Wiley: New York, 1998, 298. (b) Sugimura, T.; Ohuchi, N.; Kagawa, N.; Hagiya, K.; Okuyama, T. Chem. Lett. 2004, 33, 404. (c) Sugimura, T.; Sato, Y.; Im, C. Y.; Okuyama, T. Org. Lett. 2004, 6, 4439.

5. (a) Barton, D. H. R.; Lusinchi X.; Ramirez, J. S. Tetrahedron Lett. 1983, 24, 2995. (b) Pindur, U.; Keilhofer, D. Liebigs, Ann. Chem. 1993, 947. (c) Cookson, R. C.; Gilani, S. S. H.; 
Stevens, I. D. R. J. Chem. Soc. (C) 1967, 1905. (d) Radl, S. Adv. Heterocycl. Chem. 1997, 67, 119.

6. Maguire, A. R.; O'Leary, P.; Harrington, F.; Lawrence, S. E.; Blake, A. J. J. Org. Chem. 2001, 66, 7166.

7. (a) Morris, J. C.; Mander, L. N.; Hockless, D. C. R.. Synthesis 1998, 455. (b) Mander, L. N. Synlett, 1991, 134. (c) Mander, L. N.; Wells, A. P. Tetrahedron Lett. 1997, 38, 5709.

8. Arndt, F. Org Synth. Coll. Vol. II, 1945, 461.

9. The X-ray data for compound $\mathbf{2 9}$ has been deposited with the Cambridge Crystallographic Data Centre. The deposition number is 162992. 